\title{
Simulating secondary organic aerosol from missing diesel-related intermediate-volatility organic compound emissions during the Clean Air for London (ClearfLo) campaign
}

\author{
Riinu Ots ${ }^{1,2}$, Dominique E. Young ${ }^{3, a}$, Massimo Vieno ${ }^{2}$, Lu Xu $^{4}$, Rachel E. Dunmore ${ }^{5}$, James D. Allan ${ }^{3,6}$, Hugh Coe ${ }^{3}$, \\ Leah R. Williams ${ }^{7}$, Scott C. Herndon ${ }^{7}$, Nga L. Ng ${ }^{4,8}$, Jacqueline F. Hamilton ${ }^{5}$, Robert Bergström ${ }^{9,10}$, Chiara Di \\ Marco $^{2}$, Eiko Nemitz ${ }^{2}$, Ian A. Mackenzie ${ }^{11}$, Jeroen J. P. Kuenen ${ }^{12}$, David C. Green ${ }^{13}$, Stefan Reis ${ }^{2,14}$, and \\ Mathew R. Heal ${ }^{1}$ \\ ${ }^{1}$ School of Chemistry, University of Edinburgh, Edinburgh, UK \\ ${ }^{2}$ Natural Environment Research Council, Centre for Ecology \& Hydrology, Penicuik, UK \\ ${ }^{3}$ School of Earth, Atmospheric and Environmental Sciences, University of Manchester, Manchester, UK \\ ${ }^{4}$ School of Chemical and Biomolecular Engineering, Georgia Institute of Technology, Atlanta, GA, USA \\ ${ }^{5}$ Wolfson Atmospheric Chemistry Laboratories, Department of Chemistry, University of York, York, UK \\ ${ }^{6}$ National Centre for Atmospheric Science, University of Manchester, Manchester, UK \\ ${ }^{7}$ Aerodyne Research, Inc., Billerica, MA, USA \\ ${ }^{8}$ School of Earth and Atmospheric Sciences, Georgia Institute of Technology, Atlanta, GA, USA \\ ${ }^{9}$ Swedish Meteorological and Hydrological Institute, Norrköping, Sweden \\ ${ }^{10}$ Department of Chemistry and Molecular Biology, University of Gothenburg, Gothenburg, Sweden \\ ${ }^{11}$ School of GeoSciences, University of Edinburgh, Edinburgh, UK \\ ${ }^{12}$ TNO, Department of Climate, Air and Sustainability, Utrecht, the Netherlands \\ ${ }^{13}$ MRC PHE Centre for Environment and Health, King's College London, London, UK \\ ${ }^{14}$ University of Exeter Medical School, Knowledge Spa, Truro, UK \\ ${ }^{a}$ now at: Department of Environmental Toxicology, University of California, Davis, CA, USA \\ Correspondence to: Mathew R. Heal (m.heal@ed.ac.uk) and Riinu Ots (r.ots@ed.ac.uk)
}

Received: 12 November 2015 - Published in Atmos. Chem. Phys. Discuss.: 18 January 2016

Revised: 26 April 2016 - Accepted: 11 May 2016 - Published: 27 May 2016

\begin{abstract}
We present high-resolution $(5 \mathrm{~km} \times 5 \mathrm{~km})$ atmospheric chemical transport model (ACTM) simulations of the impact of newly estimated traffic-related emissions on secondary organic aerosol (SOA) formation over the UK for 2012. Our simulations include additional diesel-related intermediate-volatility organic compound (IVOC) emissions derived directly from comprehensive field measurements at an urban background site in London during the 2012 Clean Air for London (ClearfLo) campaign. Our IVOC emissions are added proportionally to VOC emissions, as opposed to proportionally to primary organic aerosol (POA) as has been done by previous ACTM studies seeking to simulate the effects of these missing emissions. Modelled concentrations are evaluated against hourly and daily measurements of or-
\end{abstract}

ganic aerosol (OA) components derived from aerosol mass spectrometer (AMS) measurements also made during the ClearfLo campaign at three sites in the London area. According to the model simulations, diesel-related IVOCs can explain on average $\sim 30 \%$ of the annual SOA in and around London. Furthermore, the 90th percentile of modelled daily SOA concentrations for the whole year is $3.8 \mu \mathrm{g} \mathrm{m}^{-3}$, constituting a notable addition to total particulate matter. More measurements of these precursors (currently not included in official emissions inventories) is recommended. During the period of concurrent measurements, SOA concentrations at the Detling rural background location east of London were greater than at the central London location. The model shows that this was caused by an intense pollution plume with a 
strong gradient of imported SOA passing over the rural location. This demonstrates the value of modelling for supporting the interpretation of measurements taken at different sites or for short durations.

\section{Introduction}

Ambient airborne particulate matter (PM) has diverse sources and physicochemical properties. It affects the transport, transformation, and deposition of chemical species, and has significant impacts on radiative forcing and on human health (Pöschl, 2005; USEPA, 2009). The elemental and organic carbon (EC and OC) components constitute a substantial proportion of total particle mass (USEPA, 2009; Putaud et al., 2010; AQEG, 2012). However, the characterization and source apportionment of the organic component remains a major challenge (Fuzzi et al., 2006; Hallquist et al., 2009; Jimenez et al., 2009). Understanding the sources of this organic aerosol (OA) is important in order to devise effective reduction strategies for ambient PM concentrations (Heal et al., 2012).

Organic aerosol is typically a complex mixture of thousands of organic species, the majority of which are present at low concentrations (less than a few $\mathrm{ng} \mathrm{m}^{-3}$ ). Current levels of scientific understanding, instrumentation, and modelling capability mean that explicit measurement and modelling of all individual OA species is not feasible at present. Measurement of OA by on-line mass spectrometry, such as with the Aerodyne aerosol mass spectrometer (AMS; Canagaratna et al., 2007), and consideration of individual organic marker ions coupled with multivariate statistical techniques such as positive matrix factorization (PMF; Paatero and Tapper, 1994; Paatero, 1997) have facilitated the subdivision of the OA component into empirical categories. These include hydrocarbon-like organic aerosol (HOA), oxygenated organic aerosol (OOA, which can be further split into lowvolatility and semi-volatile oxygenated organic aerosol: LVOOA and SV-OOA), solid-fuel organic aerosol (SFOA) or biomass burning organic aerosol (BBOA), cooking organic aerosol (COA), and a number of other categories (Ulbrich et al., 2009; Ng et al., 2010, 2011; Lanz et al., 2010; Young et al., 2015a). The SFOA factor includes biomass aerosols that are the so-called BBOA as well as OA from coal and charcoal combustion (Allan et al., 2010).

Even allowing for the uncertainties in defining and measuring OA components, there is a general tendency for atmospheric chemical transport model (ACTM) simulations to underestimate observed amounts of OA and SOA. For example, the AeroCom (Aerosol Comparisons between Observations and Models) project, which includes $\sim 30$ global ACTMs and global circulation models (GCMs), has concluded that the amount of OA present in the atmosphere remains largely underestimated (Tsigaridis et al., 2014). Similarly, in an eval- uation of seven global models, Pan et al. (2015) reported a systematic underestimation of OA over South Asia. Global modelling studies of SOA specifically have demonstrated huge uncertainties (up to 10-fold) in total simulated SOA budgets (Pye and Seinfeld, 2010; Spracklen et al., 2011; Jathar et al., 2011).

Several regional ACTM studies have also reported an underestimation of total OA (Simpson et al., 2007; Murphy and Pandis, 2009; Hodzic et al., 2010; Aksoyoglu et al., 2011; Jathar et al., 2011; Bergström et al., 2012; Koo et al., 2014) and SOA (Hodzic et al., 2010; Shrivastava et al., 2011; Zhang et al., 2013; Fountoukis et al., 2014), with normalized mean biases (NMBs) often in the range of -30 to $-50 \%$. In some cases, this underestimation has been shown to be due to problems with the underlying emission inventories, particularly for domestic wood burning in wintertime (Simpson et al., 2007; Denier van der Gon et al., 2015). There may also be sources of biogenic secondary organic aerosol (BSOA) arising from previously neglected VOC emissions such as those induced by biotic stress (Berg et al., 2013; Bergström et al., 2014).

Currently, ACTMs cannot explicitly simulate all the kinetic and thermodynamic processes associated with the evolving gas-phase chemistry of semi-volatile organic compounds and their partitioning to the particle phase (Donahue et al., 2014). A widely used heuristic parametrization for simulating OA is the volatility basis set (Donahue et al., 2011, 2012). The volatility (in this case the saturation concentration at $298 \mathrm{~K}, C^{*}$ ) of gas-phase organic compounds are sorted into bins: low-volatility organic compounds (LVOCs, $C^{*} \leq 0.1 \mu \mathrm{g} \mathrm{m}^{-3}$; with no lower $C^{*}$, this category also incorporates extremely low-volatility organic compounds, ELVOCs), semi-volatile organic compounds (SVOCs, $C^{*}=1-10^{3} \mu \mathrm{g} \mathrm{m}^{-3}$ ), intermediate-volatility organic compounds (IVOCs, $C^{*}=10^{4}-10^{6} \mu \mathrm{g} \mathrm{m}^{-3}$ ), and volatile organic compounds (VOCs, $C^{*} \geq 10^{7}$ ). Thus, organic compounds are distributed across a continuum from particles to gases. Under typical ambient conditions, all LVOCs, some of the SVOCs, and essentially none of the IVOCs or VOCs are in the condensed phase (Donahue et al., 2006).

Current emissions inventories, however, only report estimates for VOCs $\left(C^{*} \geq 10^{7} \mu \mathrm{g} \mathrm{m}^{-3}\right)$ and for the particle fraction of the emissions of species with lower volatilities. The main reason for this is that compounds with intermediate volatility (SVOCs and IVOCs) are difficult to quantify, and this is currently not routinely undertaken.

Robinson et al. (2007) and Shrivastava et al. (2008) estimated the mass of emitted IVOCs to be 1.5 times that of POA emissions. In their study, this addition of IVOCs $=1.5 \times$ POA was applied to all sources of POA from diesel to biomass burning. They based this estimation on chassis dynamometer tailpipe measurements by Schauer et al. (1999). Since then, several regional and global ACTM applications have adopted this factor of 1.5 (e.g. Murphy 
and Pandis, 2009; Tsimpidi et al., 2010, 2016; Hodzic et al., 2010; Jathar et al., 2011; Fountoukis et al., 2011; Genberg et al., 2011; Bergström et al., 2012; Zhang et al., 2013; Koo et al., 2014). A number of studies, including many of those cited above reporting model underestimation of OA, have highlighted the need for improved measurement and speciation of SVOCs and IVOCs and for these species to be reported in inventories.

Jathar et al. (2014) performed emissions and smog chamber experiments on SOA production from petrol and diesel vehicles. Diesel contains hydrocarbons with a higher carbon number $\left(\mathrm{C}_{8}-\mathrm{C}_{20}\right)$ than petrol (mainly $\left.\mathrm{C}_{4}-\mathrm{C}_{10}\right)$. The typical method used for hydrocarbon analysis is gas chromatography (GC); however, as the carbon number increases, the number of potential structural isomers increases exponentially, meaning $\mathrm{GC}$ is unable to distinguish individual species in the intermediate-volatility range (Goldstein and Galbally, 2007). The total carbon of this unresolved complex mixture was estimated and Jathar et al. (2014) concluded that these unspeciated organic gases dominate SOA production compared with SOA from the speciated precursors commonly included in emissions inventories (single-ring aromatics, isoprene, terpenes, and large alkenes). Jathar et al. (2014) also performed box-model simulations of the SOA budget for the US, with the addition of unspeciated emissions based on measurements by Schauer et al. (1999), and concluded that petrol contributes much more to SOA than does diesel. This result is similar to that of Bahreini et al. (2012), who, based on measurements in the Los Angeles Basin, California (CA), concluded that the contribution of diesel emissions to SOA was zero within measurement uncertainty. Conversely, Gentner et al. (2012) reported that diesel was responsible for $65-90 \%$ of vehicular-derived SOA based on measurements of gas-phase organic carbon in the Caldecoff Tunnel, CA, and in Bakersfield, CA, and on estimations of SOA yields. The huge dissimilarity in these conclusions, even in the same state in the US, emphasizes the need for continued research into petrol- and diesel-related SOA formation. Furthermore, the US and Europe have very different diesel vehicle profiles: in the US, a negligible proportion of passenger cars are diesel $(3 \%)$, whilst on average across Europe $33 \%$ of passenger cars are diesel and this proportion is increasing (Cames and Helmers, 2013). Globally, the demand for diesel fuel is increasing and by 2020 it is expected to overtake petrol as the principal transport fuel used worldwide (Exxon Mobil, 2014).

In this study, we present new high-resolution simulations of SOA formation in a 3-D ACTM model which includes additional diesel-related IVOC emissions derived directly from comprehensive field measurements of IVOCS and VOCs at an urban background site in central London (Dunmore et al., 2015) during the Clean Air for London (ClearfLo) campaign in 2012 (Bohnenstengel et al., 2014). Modelled concentrations are compared with OA components derived by PMF analysis of AMS measurements during the same cam- paign, including comparisons with the long-term measurements (full year) as well as the two month-long intensive observation periods (IOPs) in winter and summer.

\section{Methods}

\subsection{Model description}

The EMEP4UK model is a regional application of the EMEP MSC-W (European Monitoring and Evaluation Programme Meteorological Sythesizing Centre-West) model. The EMEP MSC-W model is a 3-D Eulerian model that has been used for both scientific studies and policy making in Europe. A detailed description of the EMEP MSC-W model, including references to evaluation and application studies, is available in Simpson et al. (2012), Schulz et al. (2013), and at http://www.emep.int. The EMEP4UK model is described in Vieno et al. (2010, 2014), and the model used here is based on version $\mathrm{v} 4.5$.

The EMEP4UK model uses one-way nesting from a $50 \mathrm{~km} \times 50 \mathrm{~km}$ greater European domain to a nested $5 \mathrm{~km} \times 5 \mathrm{~km}$ area covering the British Isles and parts of the near continent. The model has 21 vertical levels, extending from the ground to $100 \mathrm{hPa}$. The lowest vertical layer is $\sim 40 \mathrm{~m}$ thick, meaning that modelled surface concentrations represent the average for a $5 \mathrm{~km} \times 5 \mathrm{~km} \times 40 \mathrm{~m}$ grid cell. The model time step varies from $20 \mathrm{~s}$ (chemistry) to 5 and $20 \mathrm{~min}$ for advection in the inner and outer domains, respectively. The chemical scheme used in this study is EMEP-EmChem09soa with the MARS equilibrium module for gas-aerosol partitioning of secondary inorganic aerosol (Binkowski and Shankar, 1995; Simpson et al., 2012).

The model was driven by output from the Weather Research and Forecasting (WRF) model (http://www. wrf-model.org, version 3.1.1) including data assimilation of 6-hourly model meteorological reanalysis from the US National Center for Environmental Prediction (NCEP)/National Center for Atmospheric Research (NCAR) Global Forecast System (GFS) at $1^{\circ}$ resolution (NCEP, 2000). The WRF configuration was as follows: Lin Purdue for microphysics; Grell-3 for cumulus parametrization; Goddart Shortwave for radiation physics; and Yonsey University (YSU) for planetary boundary layer (PBL) height (see NCAR, 2008, for further information). This configuration is identical to that presented in Vieno et al. (2010), where it is shown to perform very well in comparison with measurements. No further evaluation is presented here.

\subsection{Emissions}

Gridded anthropogenic emissions of $\mathrm{NO}_{x}\left(\mathrm{NO}+\mathrm{NO}_{2}\right), \mathrm{SO}_{2}$, $\mathrm{NH}_{3}$, CO, NMVOCs (non-methane VOCs), $\mathrm{PM}_{2.5}$ (PM with aerodynamic diameter $<2.5 \mu \mathrm{m}$ ) and $\mathrm{PM}_{10}$ (PM with aerodynamic diameter $<10 \mu \mathrm{m}$ ) were obtained from NAEI ( National Atmospheric Emissions Inventory, NAEI, 2013, for the 
Table 1. SNAP source sectors as specified in the emissions input to the model (CEIP, 2015).

\begin{tabular}{ll}
\hline SNAP1 & Combustion in energy and transformation industries \\
SNAP2 & Residential and non-industrial combustion \\
SNAP3 & Combustion in manufacturing industry \\
SNAP4 & Production processes \\
SNAP5 & Extraction and distribution of fossil fuels \\
SNAP6 & Solvent and other product use \\
SNAP7 & Road transport \\
SNAP8 & Other mobile sources and machinery \\
SNAP9 & Waste treatment and disposal \\
SNAP10 & Agriculture \\
\hline
\end{tabular}

UK and from CEIP (EMEP Centre on Emission Inventories and Projections; CEIP, 2015) for the rest of the model domain. All emissions are apportioned across a standard set of emission source sectors, following the sector structure defined in the Selected Nomenclature for Air Pollutant (SNAP; EEA, 2013; Table 1), consistently applied across the whole domain.

Primary $\mathrm{PM}$ emissions reported as $\mathrm{PM}_{2.5}$ and $\mathrm{PM}_{10}$ in the NAEI and CEIP were speciated into EC, OA from fossil fuel combustion, OA from domestic combustion, and remaining primary PM by source sectors (using splits developed by Kuenen et al., 2014, as in Fig. 1). Default speciation of NMVOC emissions into 14 surrogate groups was used (Simpson et al., 2012). International shipping emissions from Entec UK Limited (now Amec Foster Wheeler) were used (Entec, 2010). The annual sectoral total emissions are temporally distributed to hourly resolution using hour-of-day, day-of-week, and monthly emission factors for each source sector as incorporated in the EMEP ACTM (Simpson et al., 2012). Daily emissions of all the aforementioned trace gases and particles from natural fires were taken from the Fire INventory from NCAR version 1.0 (FINNv1; Wiedinmyer et al., 2011). Monthly $\mathrm{NO}_{x}$ emissions from in-flight aircraft, soil, and lightning, as well as biogenic emissions of dimethyl sulfide (DMS), are included as described in Simpson et al. (2012). Biogenic emissions of isoprene and monoterpenes are calculated by the model for every grid cell and time step. Estimated emissions of wind-blown dust and sea salt are also included, but these have no impact on the model simulations of OA (Simpson et al., 2012).

\subsection{SOA production in the model}

The EMEP MSC-W model uses the 1-D volatility basis set (VBS; Donahue et al., 2006) approach for SOA formation, ageing and phase partitioning. The implementation of the VBS framework within the model, including various options for the treatment of volatility distributions and ageing reactions is described by Bergström et al. (2012).

In the model set-up used here, POA is treated as nonvolatile and inert, as is currently assumed by emissions in-

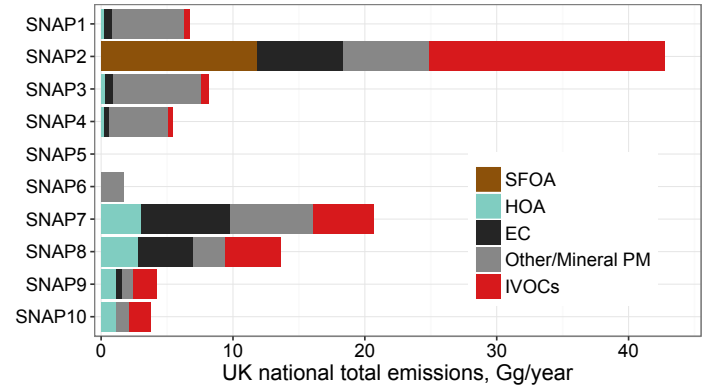

Figure 1. Annual UK $\mathrm{PM}_{2.5}$ emissions by SNAP sector (Table 1) as specified in the NAEI (for year 2012), with each sector split into POA (HOA or SFOA), EC, and remaining PM following Kuenen et al. (2014). The red bars are additional IVOCs (not included in official emission totals) that can be estimated as $1.5 \times$ the POA mass in that sector. They are included in this plot to give an indication of the relative mass of IVOC additions that have been used in other studies.

ventories. Having POA be non-volatile allows us to better identify and isolate the SOA formed from our additional diesel IVOCs. Furthermore, it has been demonstrated by Shrivastava et al. (2011) that a two-species VBS simulates an evolution of oxygen : carbon ratios $(\mathrm{O}: \mathrm{C})$ similar to the ninespecies VBS approach. The two bins of Shrivastava et al. (2011) were of volatility 0.01 and $10^{5}$, which, because material with the lower volatility is always completely in the particle phase under ambient conditions, is similar to our nonvolatile treatment of POA.

Five volatility bins $\left(C^{*}=0.1,1,10,100,1000 \mu \mathrm{g} \mathrm{m}^{-3}\right)$ are used for SOA production and ageing. The SOA yields for alkanes, alkenes, aromatics, isoprene, and terpenes under high- and low- $\mathrm{NO}_{x}$ conditions were taken from Tsimpidi et al. (2010). Note that Tsimpidi et al. (2010) reported yields for the four VBS bins between 1 and $1000 \mu \mathrm{g} \mathrm{m}^{-3}$. In this work, the lowest VBS bin $\left(0.1 \mu \mathrm{g} \mathrm{m}^{-3}\right)$ is used for the ageing reactions, as well as for SOA from the additional diesel IVOCs (explained in the next section). SOA from alkanes, alkenes, and terpenes is assumed to have an initial organic matter to organic carbon ratio (OM/OC ratio) of 1.7 , while that from isoprene and aromatics is assumed to be 2.0 and 2.1, respectively (Bergström et al., 2012; Chhabra et al., 2010). For comparison, HOA and SFOA were assumed to have $\mathrm{OM} / \mathrm{OC}$ ratios of 1.25 and 1.70 , respectively (as in Bergström et al., 2012, based on Aiken et al., 2008). Both anthropogenic SOA (ASOA; from alkanes, alkenes, and aromatics) and BSOA (from isoprene and terpenes) undergo atmospheric ageing by the hydroxyl $(\mathrm{OH})$ radical in the model (with rate coefficient of $4.0 \times 10^{-12} \mathrm{~cm}^{3}$ molecule $^{-1} \mathrm{~s}^{-1}$; Lane et al., 2008), resulting in a shift into the next lower volatility bin and a mass increase of $7.5 \%$.

A constant background OA of $0.4 \mu \mathrm{g} \mathrm{m}^{-3}$ is used to represent the contribution of OA sources not explicitly included in the model (e.g. oceanic sources or spores; Bergström et al., 
Table 2. Comparison of diesel and petrol NMVOCs in the UK National Atmospheric Emissions Inventory (NAEI) with the urban background ambient concentrations measured during the ClearfLo winter intensive observation period in London.

\begin{tabular}{lll}
\hline & $\begin{array}{l}\text { NAEI 2012 } \\
\text { (emission) }\end{array}$ & $\begin{array}{l}\text { Measurements* } \\
\text { (concentration) }\end{array}$ \\
\hline Diesel (I)VOCs & $8 \mathrm{Gg} \mathrm{yr}^{-1}$ & $107 \mu \mathrm{g} \mathrm{m}^{-3}$ \\
Petrol VOCs & $31 \mathrm{Gg} \mathrm{yr}^{-1}$ & $33 \mu \mathrm{g} \mathrm{m}^{-3}$ \\
Diesel/petrol & 0.26 & 3.2 \\
\hline
\end{tabular}

* Dunmore et al. (2015).

2014). This background OA is assumed to be highly oxygenated and is therefore included under modelled SOA when comparing with observations (with an $\mathrm{OM} / \mathrm{OC}$ ratio of 2.0 it is also assumed to be non-volatile).

\subsection{Additional IVOCs from diesel}

Current emissions inventories report highly volatile anthropogenic VOCs of $C^{*} \geq 10^{7} \mu \mathrm{g} \mathrm{m}^{-3}$ (Passant, 2002). However, diesel vehicles also produce substantial emissions of species with intermediate volatility in the range $10^{5} \leq C^{*} \leq 10^{6} \mu \mathrm{g} \mathrm{m}^{-3}$ (IVOCs), as has been shown by Dunmore et al. (2015) from measurements made at an urban background site in central London during the ClearfLo project.

In this study, aliphatic IVOC emissions from diesel vehicles were introduced into the model proportionally to on-road transport VOC emissions, using $n$-pentadecane $\left(\mathrm{C}_{15} \mathrm{H}_{32}\right)$ as a surrogate for the following reasons. First, the amount of alkenes in diesel fuel is low ( $<5 \%$; Gentner et al., 2012), so an alkane is the most appropriate surrogate. Second, all $n$-alkanes up to $n$-dodecane were individually speciated and quantified during two month-long intensive observation periods (IOPs) during the ClearfLo project and there were strong correlations between all $n$-alkanes that have a predominately diesel source (Dunmore et al., 2015). Third, the rate constant for the linear alkane is a reasonable representation of the rate constant for all the (unmeasured) branched and cyclic isomers, as demonstrated by Dunmore et al. (2015) for the $C_{12} n$-alkane, dodecane. The bulk of diesel emissions, however, are likely to have higher carbon numbers than were measured by a comprehensive twodimensional gas chromatography $(\mathrm{GC} \times \mathrm{GC})$ system (Dunmore et al., 2015). The rate coefficient for the reaction between $n$-pentadecane and $\mathrm{OH}$ has been measured in a number of studies $\left(k=2.07 \times 10^{-11} \mathrm{~cm}^{3}\right.$ molecule ${ }^{-1} \mathrm{~s}^{-1}$; Atkinson and Arey, 2003) unlike for the majority of branched isomers in this range. Furthermore, measurements of diesel fuel composition have shown that the average carbon number on a percentage weight basis was 14.94 (Gentner et al., 2012), so

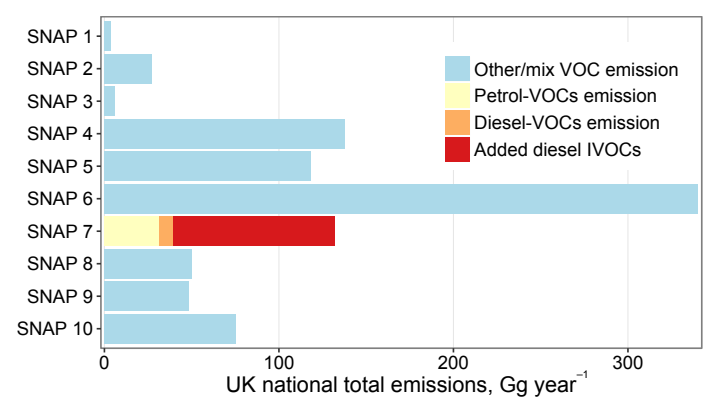

Figure 2. Annual UK NMVOC emissions by SNAP sector (Table 1) as specified in the NAEI (for the year 2012), with the SNAP7 emissions subdivided into petrol and diesel vehicles, and with the additional diesel-associated IVOC emissions input to the model in this study shown in red.

$n$-pentadecane was considered to be an appropriate surrogate for diesel emissions in general.

In the NAEI, emissions from petrol vehicles dominate the NMVOC emissions from road traffic, but measurements during the ClearfLo winter IOP showed that NMVOCs assigned to diesel vehicles dominated traffic-related NMVOC concentrations. The amount of pentadecane emitted in the model was therefore set to match the measured diesel-(I)VOC (IVOCs + VOCs) to petrol-VOC ratio (Table 2, Fig. 2). This pentadecane addition was then applied to every country in the model domain using the same factor as for the UK. This first approximation is justified because the fleet share of diesel vehicles in the UK is similar to the European average $(\sim 30 \%$; EEA, 2010), but it can introduce errors for specific countries.

For the oxidation products of $\mathrm{C}_{15} \mathrm{H}_{32}$, SOA mass yields were taken from Presto et al. (2010): 0.044, 0.071, 0.41, and 0.30 for the $0.1,1,10$, and $100 \mu \mathrm{g} \mathrm{m}^{-3}$ bins, respectively (Presto et al., 2010, did not report a yield for the $1000 \mu \mathrm{g} \mathrm{m}^{-3}$ bin). These yields are reported for SOA with unit density $\left(1 \mathrm{~g} \mathrm{~cm}^{-3}\right)$. In this work, SOA density was assumed to be $1.5 \mathrm{~g} \mathrm{~cm}^{-3}$ (Tsimpidi et al., 2010; Bergström et al., 2012) and the yields were increased accordingly.

For the UK, our approach adds $90 \mathrm{Gg}$ of diesel-IVOC emission for the year 2012 (Fig. 2). The $1.5 \times$ POA approach (Shrivastava et al., 2008, based on measurements by Schauer et al., 1999) would only add $31 \mathrm{Gg}$ (Fig. 1). Part of this discrepancy could be attributable to the different methods and circumstances used to derive the additions (this work: 5 weeks of ambient measurements in a megacity; previous estimate: tailpipe laboratory measurements using different instruments). Another possible reason for the difference is an underestimate in POA emissions in the inventory; more POA would increase the amount of proportionally added IVOCs. However, Dunmore et al. (2015) show that lower-carbon-number (and higher-volatility) NMVOCs measured during the ClearfLo campaign were consistent with emissions estimates. This lends confidence to adding IVOCs proportionally to reported NMVOC emissions, rather than 
proportionally to POA emissions. Nevertheless, we have also performed a model run using the POA-based IVOC estimate, also including the semi-volatile treatment of POA. The emitted semi-volatile POA (SVOCs) and $1.5 \times$ POA IVOCs are assigned to nine VBS bins $-0.03 \times \mathrm{POA}, 0.06 \times \mathrm{POA}$, $0.09 \times \mathrm{POA}, \quad 0.14 \times \mathrm{POA}, \quad 0.18 \times \mathrm{POA}, \quad 0.30 \times \mathrm{POA}$, $0.40 \times$ POA, $0.50 \times$ POA, $0.80 \times$ POA to the bins $0.01-10^{6}$, respectively - totalling $2.5 \times \mathrm{POA}$ (Shrivastava et al., 2008). Both SVOCs and IVOCs then go through atmospheric ageing with $\mathrm{OH} \quad\left(k=4.0 \times 10^{-11} \mathrm{~cm}^{3}\right.$ molecule ${ }^{-1} \mathrm{~s}^{-1}$; Shrivastava et al., 2008). In this case, the additional IVOCs were calculated from POA from all sources, not just trafficrelated. Note that in the UK, most of the additional IVOCs of the POA-based approach would come from SNAP2 (residential and non-industrial combustion emissions; Fig. 1): $18 \mathrm{Gg}$, whereas only $5 \mathrm{Gg}$ would be added to SNAP7 (road transport; and $8 \mathrm{Gg}$ to remaining sectors). SVOCs and IVOCs that have undergone at least one ageing shift and are in the particulate phase are included under SOA (in addition to ASOA and BSOA from VOCs as in the Base case). Due to the very different absolute amounts and source categories (the latter of which also leads to differences in the spatial pattern and temporal variation of the additional emissions), detailed comparison of the two different additions is not justified, and only annual total OA component budgets of the different addition methodologies are presented.

\subsection{Summary of model experiments}

Three runs of the EMEP4UK modelling system were performed for 2012:

- Base: all anthropogenic emissions as in officially reported inventories; emissions of biogenic VOCs are calculated by the model for each advection time step.

- addDiesel: Base + additional diesel IVOCs added proportionally to NMVOC emissions from traffic $(2.3 \times$ SNAP7). The additional IVOCs were treated using $n$-pentadecane as surrogate species. The semivolatile VBS species formed after oxidation of $n$ pentadecane were treated in the same way as the ASOA species from VOC oxidation (the same ageing rate and mass increase due to oxygen addition; see Sect. 2.3).

- 1.5volPOA: semi-volatile treatment of POA + additional IVOCs added proportionally to all POA emissions $(1.5 \times$ POA; as in Shrivastava et al., 2008, based on measurements by Schauer et al., 1999). Inclusion of anthropogenic and biogenic VOCs as in Base.

\subsection{Comparison with measurements}

Modelled $\mathrm{OA}_{2.5}$ (OA with diameter $<2.5 \mu \mathrm{m}$ ) is compared with non-refractory submicron $\left(\mathrm{NR}-\mathrm{PM}_{1}\right) \mathrm{OA}$ measured by

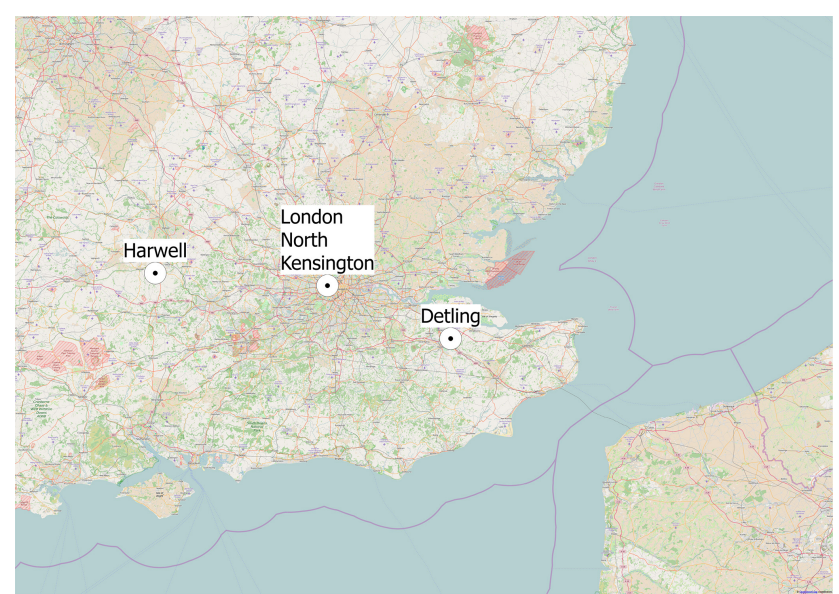

Figure 3. Locations of measurement sites used in this study. London North Kensington is an urban background site, and Harwell and Detling are rural background sites. Underlying map from ${ }^{\circ}$ OpenStreetMap contributors.

Aerodyne AMS instruments at an urban background site in central London and at two rural sites (Xu et al., 2016; Young et al., 2015a, b; Bohnenstengel et al., 2014; site locations are shown in Fig. 3). The error introduced to the comparison by the different size fractions is believed to be small, as measurements at an urban background site in Birmingham, England have shown that $90 \%$ of organic carbon in $\mathrm{PM}_{2.5}$ is in the submicron fraction (Harrison and Yin, 2008).

Different types of AMS were deployed in this campaign. At the London North Kensington site a compact time-offlight AMS (cToF-AMS) was deployed for a full calendar year (January 2012-January 2013), and a high-resolution time-of-flight AMS (HR-ToF-AMS) was also deployed for the IOPs at the same site. A HR-ToF-AMS was deployed in Detling during the winter IOP, and in Harwell during the summer IOP. PMF analysis was applied to each of the data sets to apportion measured OA into different components (Ulbrich et al., 2009). A detailed description of the derivation and optimization of the factors retrieved from the AMS data at Detling can be found in Xu et al. (2016), at London North Kensington in Young et al. (2015a, b) (all three of these analyses were performed with the PMF2 solver), and at Harwell in Di Marco et al. (2016) (using the ME-2 solver). The OM/OC ratios for each of the PMF data sets presented in this study were calculated with the ImprovedAmbient method from Canagaratna et al. (2015). A summary of the instruments, measurement periods, and resolved PMF factors is given in Table 3. As our emissions inventory does not include cooking OA (NAEI, 2013), this factor could not be compared with the model.

When AMS measurements and their PMF apportionments are compared, some disagreement is observed, as shown for the two instruments measuring at the same time at the same location at London North Kensington. This is in part due to 
Table 3. AMS measurements and resolved PMF factors during the ClearfLo campaign and the allocation of the PMF factors to SOA for comparison with model simulations. Site locations are shown in Fig. 3. Site names are abbreviated as follows: NK - London North Kensington; DET - Detling; HAR - Harwell.

\begin{tabular}{|c|c|c|c|c|c|}
\hline \multirow[b]{2}{*}{ Period } & \multirow[b]{2}{*}{ Site } & \multirow[b]{2}{*}{ Dates (year 2012) } & \multirow[b]{2}{*}{ Instrument } & \multicolumn{2}{|c|}{ PMF factors } \\
\hline & & & & Primary & Secondary \\
\hline \multirow[t]{2}{*}{ Winter IOP } & NK & 13 Jan-8 Feb & HR-ToF-AMS & HOA, SFOA1, SFOA2, COA & OOA \\
\hline & DET & 20 Jan-14 Feb & HR-ToF-AMS & HOA, SFOA & OOA \\
\hline \multirow[t]{2}{*}{ Summer IOP } & NK & $21 \mathrm{Jul}-19$ Aug & HR-ToF-AMS & HOA, COA, unknown & SV-OOA, LV-OOA \\
\hline & HAR & 3 Aug-20 Aug & HR-ToF-AMS & HOA & SV-OOA, LV-OOA, N-OOA \\
\hline Annual & NK & 11 Jan-24 Jan $(2013)^{*}$ & cToF-AMS & $\mathrm{HOA}, \mathrm{SFOA}^{* *}, \mathrm{COA}$ & OOA $1, \mathrm{OO} 2^{* *}$ \\
\hline
\end{tabular}

* As the cToF-AMS was retuned before the summer IOP and retuned to the previous tuning at the end of the IOP, the subsequent data could not be used in the PMF analysis (see Young et al. (2015a) for details). However, for the purpose of the comparison in this study, data from the HR-ToF-AMS, deployed at the same site during the summer IOP, were used to fill in this period. ** PMF analysis revealed the SFOA and OOA2 factors were convolved due to their similar, strong diurnal cycles. Daily averages have been used to estimate their concentrations (Young et al., 2015a).

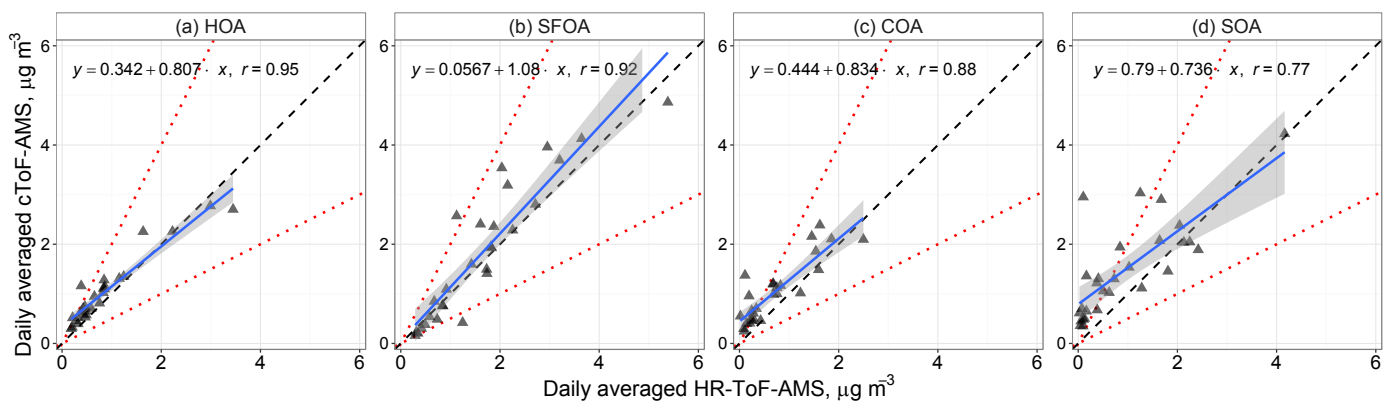

Figure 4. Scatter plots of PMF-derived OA component concentrations - (a) HOA, (b) SFOA, (c) COA, and (d) SOA - based on different AMS instruments at the London North Kensington site during the winter IOP. The dashed lines are the $2: 1,1: 1$, and $1: 2$ lines.

the differences in the types of AMS used, where more chemical information is retrieved from the HR-ToF-AMS, which can subsequently lead to differences in the derived PMF factors from the individual data sets. It should also be kept in mind that PMF was run on each of the full data sets, covering a full year for the cToF-AMS and only four weeks for each of the HR-ToF-AMS IOPs; thus, it is not necessarily expected that the same PMF factors would be derived from the different data sets. Nevertheless, strong correlations between daily averaged primary OA components from the two instruments deployed at the London North Kensington site during the winter IOP are observed $(0.95,0.92$, and 0.88 for HOA, SFOA, and COA, respectively), with less strong correlations for SOA (0.77). Scatter plots of these PMF derived OA component concentrations resolved for the cToF-AMS data and HR-ToF-AMS are shown in Fig. 4. This inherent uncertainty in the measurements constrains the expected correlation with the model.

The following numerical metrics were used for model evaluation:

- FAC2 (factor of 2): the proportion of modelled concentrations that are within a factor of 2 of the measured concentrations.
- NMB: normalized mean bias.

- NMGE: normalized mean gross error, which is defined as

$\mathrm{NMGE}=\frac{\frac{1}{n} \sum_{i=1}^{n}\left|M_{i}-O_{i}\right|}{\bar{O}}$,

where $M_{i}$ is the $i$ th modelled value, $O_{i}$ is the corresponding measured value, $\bar{O}$ is the mean measured value, and $n$ in the total number of observations.

- $r$ : correlation coefficient.

- COE: coefficient of efficiency, which is defined as

$$
\mathrm{COE}=1.0-\frac{\sum_{i=1}^{n}\left|M_{i}-O_{i}\right|}{\sum_{i=1}^{n}\left|O_{i}-\bar{O}\right|} .
$$

A COE of 1 indicates perfect agreement between model and measurements. Although the COE does not have a lower bound, a zero or negative $\mathrm{COE}$ implies that the model cannot 
explain any of the variation in the observations (Legates and McCabe, 2013).

Seasons are defined as follows: winter - DecemberJanuary-February (DJF); spring - March-AprilMay (MAM); summer - June-July-August (JJA); and autumn - September-October-November (SON).

\section{Results}

The comparisons between the model results and measurements are presented in the following order. First, comparisons are presented for primary $\mathrm{OA}, \mathrm{NO}_{x}, \mathrm{O}_{3}$, and for secondary inorganic aerosol (SIA) to give an overview of the overall performance of the modelling system. Second, the hourly concentrations of SOA during the two IOPs are evaluated, demonstrating the agreement between the model and measurements at high temporal resolution. Third, the yearlong daily SOA concentrations are compared and the relative impact of diesel VOCs on SOA production in London is shown. Fourth, modelled and measured OM/OC ratios are shown. Finally, annual total ASOA from our method and the previous $1.5 \times$ POA approach are compared.

\subsection{POA, $\mathrm{NO}_{x}, \mathrm{O}_{3}$, SIA: annual data set}

Figure 5 shows the year-long comparison between the daily averaged model results and the cToF-AMS measurements at the London North Kensington site. The model underestimates primary OA (HOA and SFOA) concentrations (NMB of -54 and $-71 \%$, respectively) but shows good daily correlations ( $r$ values of 0.53 and 0.72 , respectively). The underestimation of HOA may be caused by a combination of lack of model resolution (e.g. the minor road close to the measurement site can not be resolved with the $5 \mathrm{~km}$ grid), and underestimation of PM emissions. Modelled $\mathrm{NO}_{x}$ concentrations are relatively less underestimated in comparison to measurements (NMB of $-32 \%$, Fig. 6a), suggesting that HOA emissions may be more underestimated than the emissions of $\mathrm{NO}_{x}$. Concentrations of secondary inorganic pollutants are simulated well by the model in the gas phase (Fig. 6b, with a NMB of $-1 \%$ for ozone) and for inorganic PM constituents (Fig. 6c-d), with NMBs of $6 \%$ for $\mathrm{SO}_{4}^{2-},-12 \%$ for $\mathrm{NH}_{4}^{+}$, and $-23 \%$ for $\mathrm{NO}_{3}^{-}$.

\subsection{Hourly comparison of secondary OA: summer IOP}

Evaluation statistics between hourly measured and modelled SOA concentrations in July and August 2012 (summer IOP) show excellent agreement (Fig. 7). The values of $r$ for the Base run were 0.67 and 0.55 at North Kensington and Harwell, respectively. The addDiesel experiment yields a modest improvement in the value of $r$ at North Kensington (to 0.76) and a marked improvement in Harwell (to 0.74). The addDiesel run substantially improves the NMB for SOA at the Harwell and London North Kensington sites from
-32 to $-5 \%$ and from -35 to $0.1 \%$, respectively (Fig. 7). This means that $\sim 30 \%$ of SOA at both sites during this period can be explained by the diesel IVOCs added into the model using pentadecane as a surrogate. There is also marked improvement of model-measurement COE values at the two sites (Harwell, 0.26 to 0.42 ; NK, 0.31 to 0.45 ). The improvement in NMGE is noticeable (Harwell, 54 to $43 \%$; NK, 59 to $47 \%$ ), but smaller than the improvements in the other metrics. It can be seen from the scatter plots in Fig. 8 that most modelled hourly SOA concentrations fall within a factor of 2 of the measured concentrations (FAC2 for the addDiesel experiment is $78 \%$ at Harwell and $62 \%$ at NK).

Measured and modelled mean hour-of-day variations of SOA concentrations are presented in Fig. 9, where it can be seen that measured SOA concentrations do not have a very strong diurnal cycle. Interestingly, both sites exhibit dips in measured SOA concentrations in the morning and early evening. Both measured and modelled SOA concentrations in London North Kensington reach a maximum in the afternoon, but SOA of the addDiesel experiment starts this increase earlier than the measurements, meaning that our ASOA production from pentadecane might be too rapid.

During the summer IOP, there were two sustained episodes of increased SOA concentrations: 23 to 28 July and 9 to 13 August (Fig. 7). Only London North Kensington had measurements during the first episode and the elevated concentrations were well captured by the addDiesel simulation (including the highest peak of greater than $16 \mu \mathrm{g} \mathrm{m}^{-3}: 27$ July 13:00 GMT, Fig. 10b). Daily averaged SOA maps (Fig. 11) suggest that this first episode arose from a combination of SOA transported from Europe and SOA produced locally in London. A region of elevated concentration around London exists within a general gradient of SOA from continental Europe to southern England. Even daily averaged concentrations are spatially variable during this episode meaning that inaccuracies in some of the modelled peaks can be attributed to uncertainties in the underlying meteorological model. Most of the modelled SOA during this episode was of anthropogenic origin with the addDiesel run yielding a significant portion of ASOA from pentadecane.

For the second sustained episode of high SOA concentrations, from 9 to 13 August, several features remain substantially underestimated even in the addDiesel run. For Harwell, the model captures two of the highest peaks (10 August 22:00 GMT measured: $6.8 \mu \mathrm{g} \mathrm{m}^{-3}$, addDiesel: $8.5 \mu \mathrm{g} \mathrm{m}^{-3}$; 12 August 12:00 GMT measured: $7.9 \mu \mathrm{g} \mathrm{m}^{-3}$, addDiesel: $7.0 \mu \mathrm{g} \mathrm{m}^{-3}$ ), but for London North Kensington, the model simulates a minimum during the highest measured concentration (10 August 05:00 GMT measured: $11.9 \mu \mathrm{g} \mathrm{m}^{-3}$, addDiesel: $2.0 \mu \mathrm{g} \mathrm{m}^{-3}$ ). The high concentrations during the first 2 days of this episode were very localized with horizontal widths of just tens of kilometres (Fig. 12a and b). There was a build-up of pollution caused by high pressure and low boundary layer height (BLH), which led to production of ASOA in London. The high variability in the modelled con- 


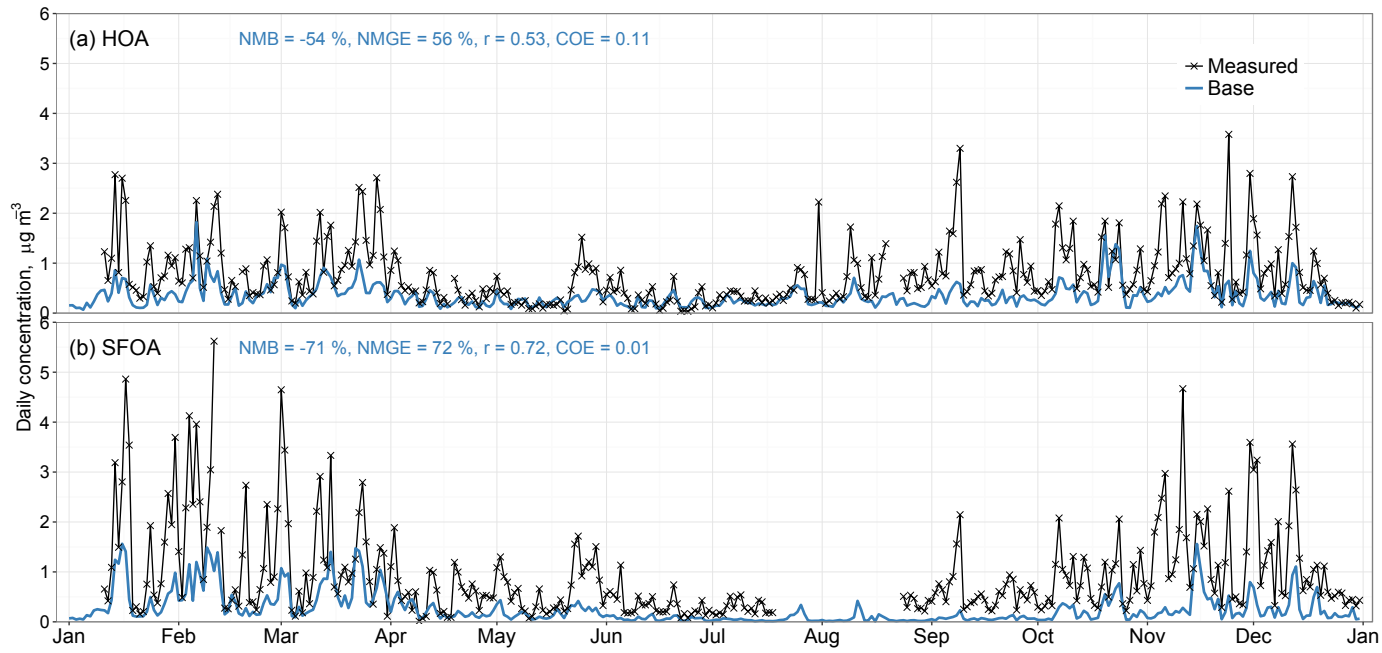

Figure 5. Time series of measured and modelled daily average concentrations of (a) HOA, and (b) SFOA at the London North Kensington urban background site, 2012, measured with the cToF-AMS (Table 3).

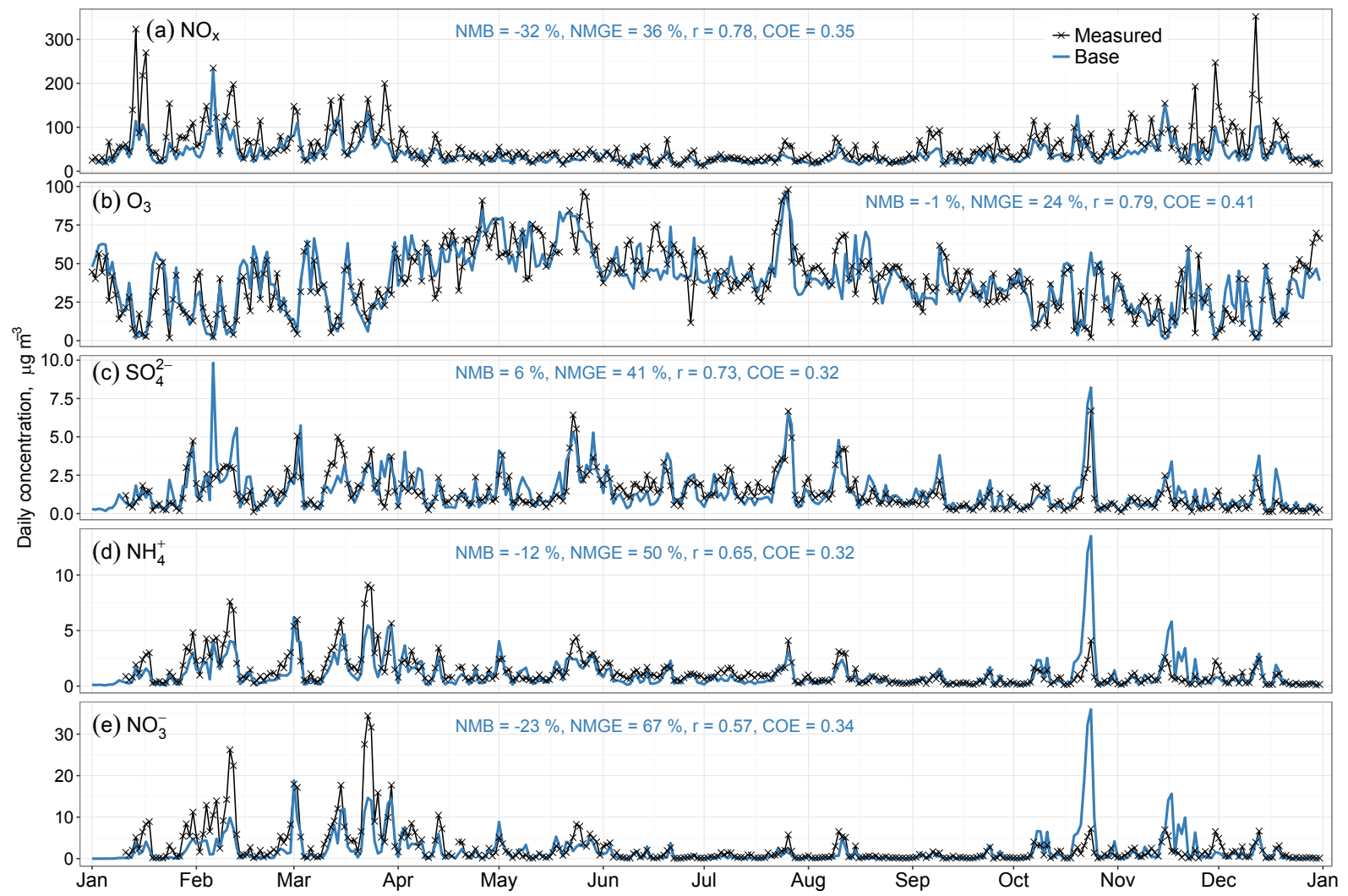

Figure 6. Time series of measured and modelled daily average concentrations of (a) $\mathrm{NO}_{x}\left(\right.$ as $\left.\mathrm{NO}_{2}\right)$, (b) $\mathrm{O}_{3}$, (c) $\mathrm{SO}_{4}^{2-}$, (d) $\mathrm{NH}_{4}^{+}$, and (d) $\mathrm{NO}_{3}^{-}$at the London North Kensington urban background site, 2012. Measurement data of $\mathrm{NO}_{x}$ and $\mathrm{O}_{3}$ are from the UK Automated Urban and Rural Network (AURN); $\mathrm{SO}_{4}^{2-}, \mathrm{NH}_{4}^{+}$, and $\mathrm{NO}_{3}^{-}$were measured with the cToF-AMS (Table 3). 


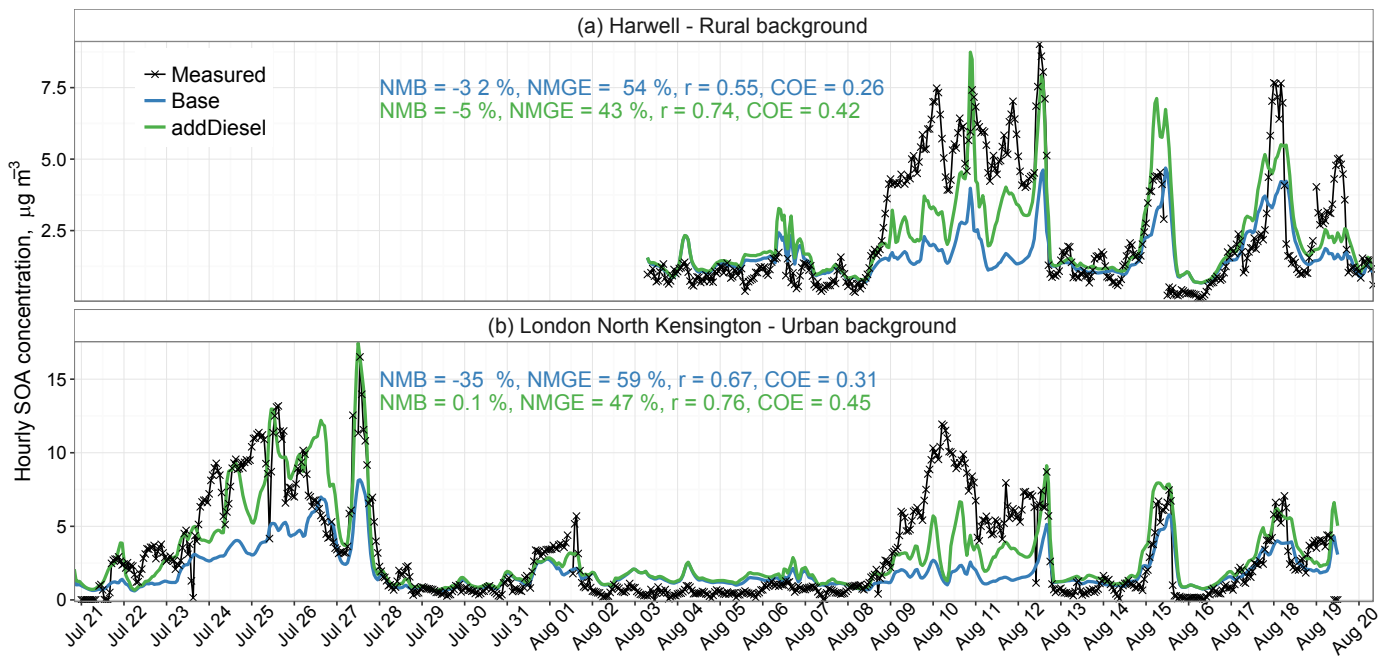

Figure 7. Time series of measured and modelled hourly average concentrations at (a) the Harwell rural background site, and (b) the London North Kensington urban background site during the summer IOP. Note the different scales on the $y$ axes.

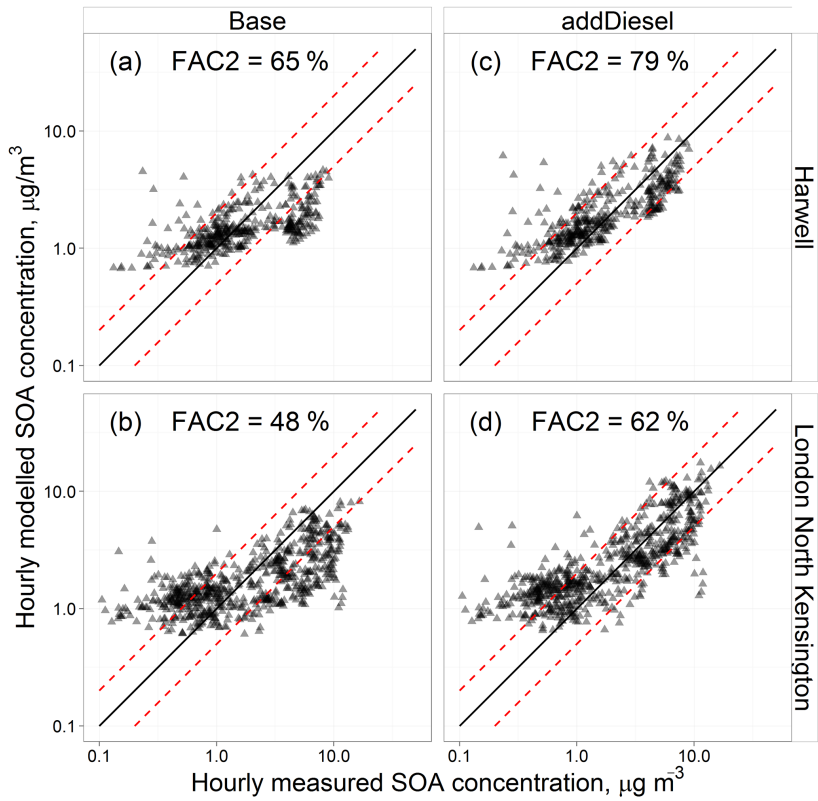

Figure 8. Scatter plots of measured and modelled hourly SOA concentrations during the summer 2012 IOP: (a) Base simulation at the Harwell rural background site; (b) Base simulation at the North Kensington urban background site; (c) addDiesel simulation at the Harwell rural background site; (d) addDiesel simulation at the North Kensington urban background site. The straight lines are the $2: 1,1: 1$, and $1: 2$ lines.

centrations (for example, the simulated minimum during the measured maximum at North Kensington) is caused by the shifting of this narrow ASOA plume in space (Fig. 10b). On 12 August, this episode was also subject to SOA contribution from Europe (Fig. 12d).

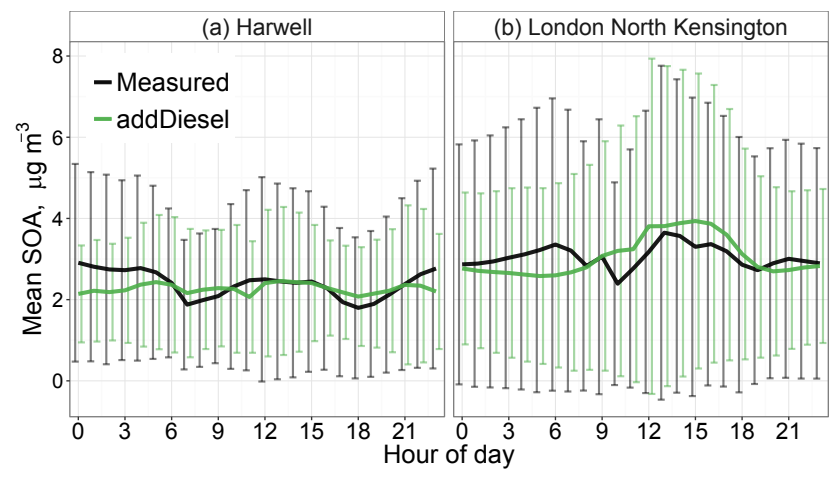

Figure 9. Average hourly profiles of modelled (addDiesel experiment) and measured SOA during the summer IOP. Also shown are the standard deviations for each mean value.

During the period of overlapping measurements at Harwell and North Kensington (3-18 August), both the measurements and the model agree with a modest rural to urban increase. Average measured SOA concentrations were 2.4 and $2.6 \mu \mathrm{g} \mathrm{m}^{-3}$ for Harwell and North Kensington, respectively, whilst average modelled concentrations were 2.3 and $2.5 \mu \mathrm{g} \mathrm{m}^{-3}$ (for the addDiesel experiment).

\subsection{Hourly comparison of secondary OA: winter IOP}

Both the Detling and London North Kensington sites exhibit good model-measurement hourly correlation $(r=0.63$ and 0.64, addDiesel run; Fig. 13). The addDiesel run decreases the NMB for SOA at these sites from -59 to $-30 \%$ for Detling, and from -24 to $8 \%$ for London North Kensington. This means that $\sim 30 \%$ of SOA at these sites during this period can be explained by diesel IVOCs. In Detling, there is also a pronounced improvement in the COE, 

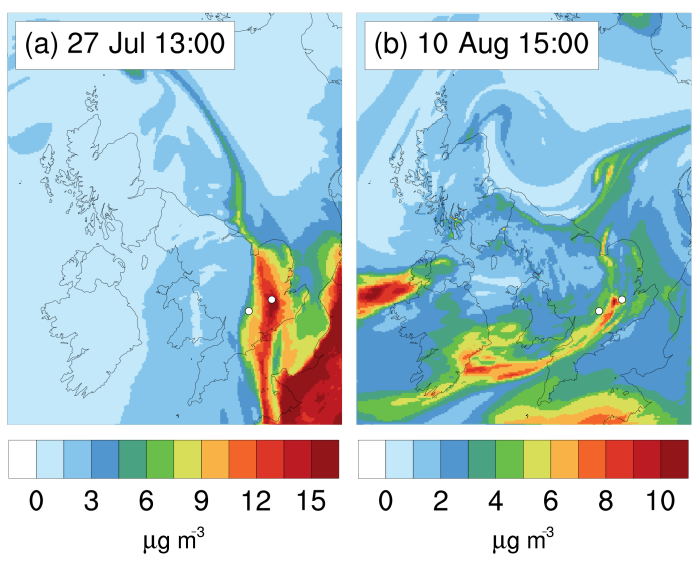

Figure 10. Modelled (addDiesel experiment) hourly concentrations of SOA at the time of the maximum measured hourly SOA value at the London North Kensington site during the first and second SOA episodes of the summer IOP. The white circles mark the measurement site locations - left: Harwell; right: London North Kensington.

from 0.10 to 0.31 . In North Kensington, the COE was already high but is increased from 0.27 to 0.30 . It can be seen in Fig. 13 as well as Fig. 14 that lower concentrations of SOA (19-27 January) are overestimated by the model. This overestimation is caused by the very simplified method of including missing sources of OA using a constant concentration of $0.4 \mu \mathrm{g} \mathrm{m}^{-3}$ (which is assumed to be highly oxygenated and is therefore included under modelled SOA). As a constant, this background OA does not currently go through atmospheric emission-removal processes in the model. However, the period in question exhibited snowfall, removing much of the aerosol (as can be seen from the very low concentrations measured in both Detling and London North Kensington). Explicit inclusion of additional missing biogenic sources of OA to the model is already part of ongoing development of the model and will be presented in future studies.

During the ClearfLo Winter IOP, measured SOA concentrations were higher in Detling than in North Kensington (Fig. 13). This is correctly captured by the simulations and is caused by a steep positive gradient of concentrations from southern England across to the near European continent (Fig. 15). The measured Detling / North Kensington SOA ratio (ratio of average concentrations for this period) was 1.8 , while the modelled ratio was 1.1 , so the model correctly simulates the direction of the spatial gradient, but underestimates its magnitude. For North Kensington, the model also captures that SOA concentrations are lower on 5 February than on 4 February. In Detling, however, measured concentrations were higher on 5 February, which the model does not reproduce. During the night of 4-5 February, the wind was very strong $\left(>10 \mathrm{~m} \mathrm{~s}^{-1}\right)$ and there was a small shift between the measured wind direction and the wind direction input to EMEP4UK from WRF. As a consequence, the simulated pollution plume was shifted too much to the east (Fig. 15b), causing the model-measurement discrepancy on this particular occasion.

Even though the additional diesel IVOCs noticeably increased the modelled SOA concentrations during the winter IOP, there is still a marked underestimation of elevated measured SOA concentrations during 15-19 January and 30 January-4 February. During these periods, the observed temperature was colder than the average temperature of the winter IOP (Crilley et al., 2015) and peaks in measured SOA also coincide with elevated concentrations of SFOA (Figs. 5b and 13b). As our modelled SFOA is underestimated by a factor of 4 (NMB of $-72 \%)$, it is likely that (i) SOA precursor VOC emissions from domestic heating are also underestimated, and (ii) adding missing IVOCs from this emission sector would contribute to the modelled SOA during these periods. It has been recently shown by Denier van der Gon et al. (2015) that the emission factors used by different European countries for wood combustion PM emissions, even for the same appliance type, can differ by a factor of 5 . They constructed a revised inventory, in which each country's emission was updated using an unified emission factor. This resulted in increases of PM (and estimated accompanying IVOC) emission estimates for most countries. Furthermore, London is a smoke control area and therefore no residential emissions of SFOA are assumed by the national emissions inventory. Recent studies have, however, suggested that there are indeed local sources of SFOA in London (Crilley et al., 2015; Young et al., 2015a).

\subsection{Daily and seasonal secondary OA: annual data set}

Time series of daily averaged modelled and measured SOA concentrations for the whole year are shown in Fig. 16. Table 4 gives daily modelled vs. measured SOA evaluation statistics during different seasons at the North Kensington site. Values for autumn are presented with and without the two extreme points (size of the data set $n=91$ and $n=89$ ).

For the daily model-measurement comparison, spring has the highest correlation $(r=0.85$, both Base and addDiesel; Table 4). This can also be seen from the time series (Fig. 16: March-May) where both model simulations follow most of the measured peaks. The Base run $r$ value for spring was already high, but, nevertheless, the addDiesel run shows a marked improvement for all other model evaluation statistics. FAC2 is increased by $10 \%, \mathrm{COE}$ is increased to 0.39 , NMB is reduced by $35 \%$, and NMGE is reduced by $7 \%$. The NMGE of $38 \%$ remaining in the addDiesel model run is probably governed by uncertainties in meteorology, as well as by uncertainties in the temporal and spatial variability of emissions. During summer, the model captures the majority of the periods of increased SOA mass well (e.g. 28 June, 2229 July, 15 and 20 August; Fig. 16: June-August), but there is some model underestimation when SOA concentrations were lower $\left(<2 \mu \mathrm{g} \mathrm{m}^{-3}\right)$. As for spring, the addDiesel experiment improves all model evaluation statistics. More detailed 


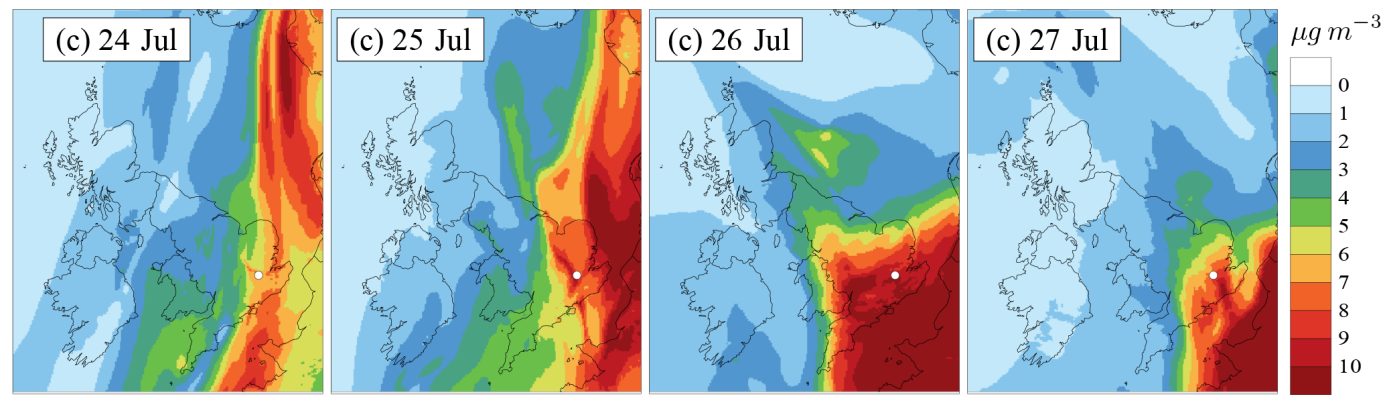

Figure 11. Modelled (addDiesel experiment) daily average concentrations of SOA during the first SOA episode of the summer 2012 IOP. The white circle indicates the location of London North Kensington.
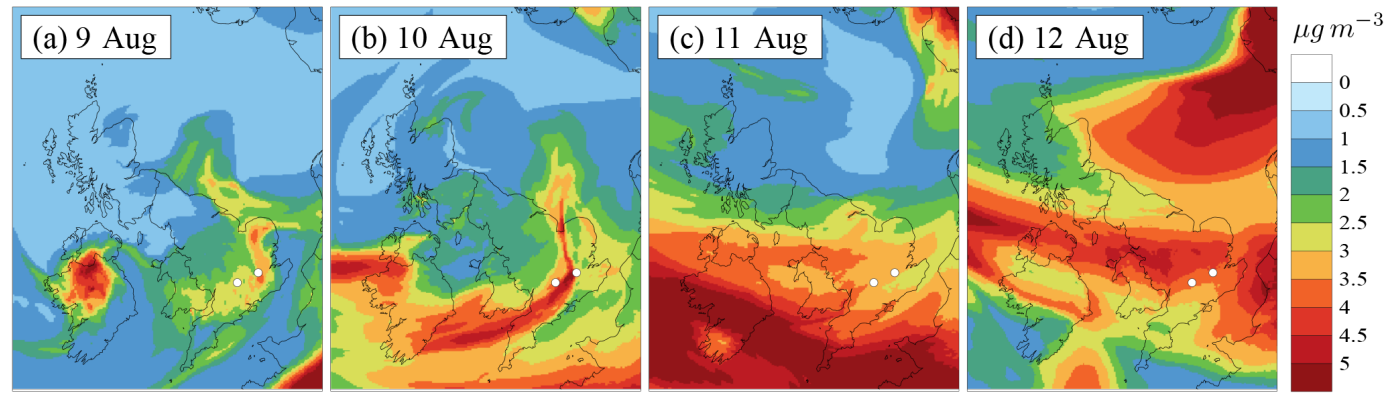

Figure 12. Modelled (addDiesel experiment) daily average concentrations of SOA during the second SOA episode of the summer 2012 IOP. The white circles mark the measurement site locations - left: Harwell; right: London North Kensington.

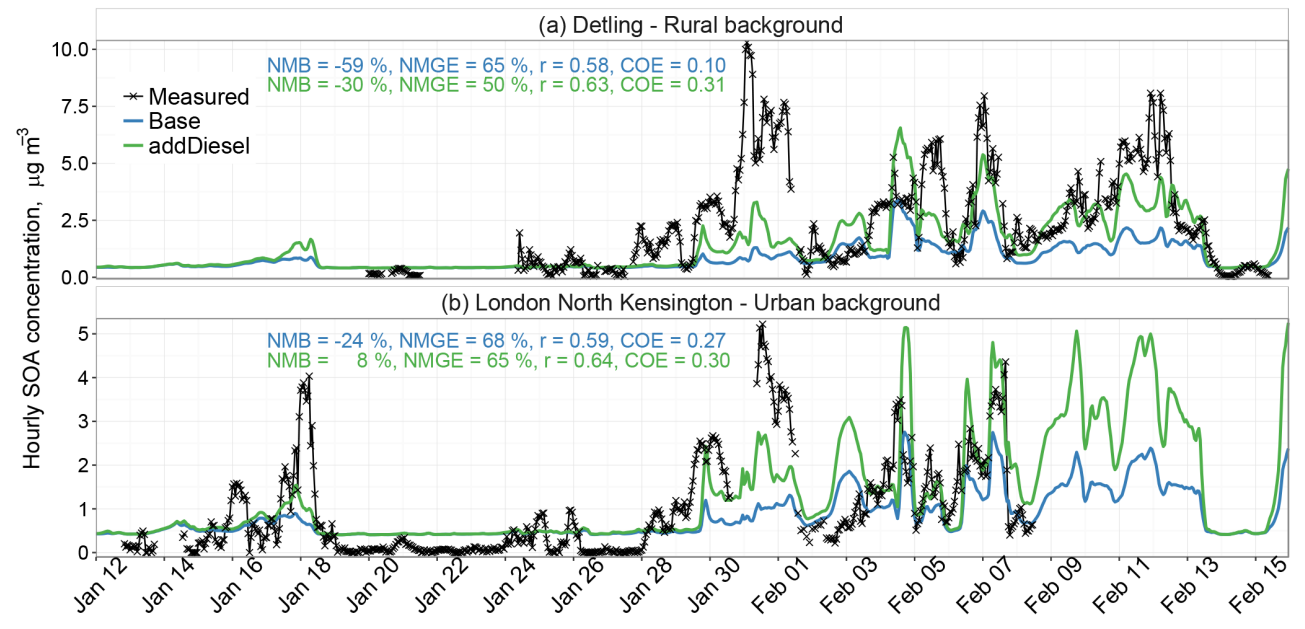

Figure 13. Time series of measured and modelled hourly average concentrations at (a) the Detling rural background site, and (b) the London North Kensington urban background site during the winter 2012 IOP. Note the different scales on the $y$ axes.

hourly analysis of the SOA concentrations during the summer IOP (end of July to August) was presented in Sect. 3.2.

The model performance is less good in autumn than during the other seasons. There are some days where the Base case scenario overestimates measured SOA (23-25 October, 21 and 24 November) with the addDiesel run increasing this further. During these days, particle nitrate $\left(\mathrm{NO}_{3}^{-}\right)$ and ammonium $\left(\mathrm{NH}_{4}^{+}\right)$are also substantially overestimated by the model (Fig. 6). This suggests that the overestimations are likely caused by errors occurring during this period in the meteorological forecasts, e.g. missed rain events, rather than by uncertainties in the formation of secondary organic aerosol specifically.

The model evaluation statistics for autumn are strongly influenced by the two modelled values on 23 and 24 October (Table 4). Removing these two values reduces the seasonal 


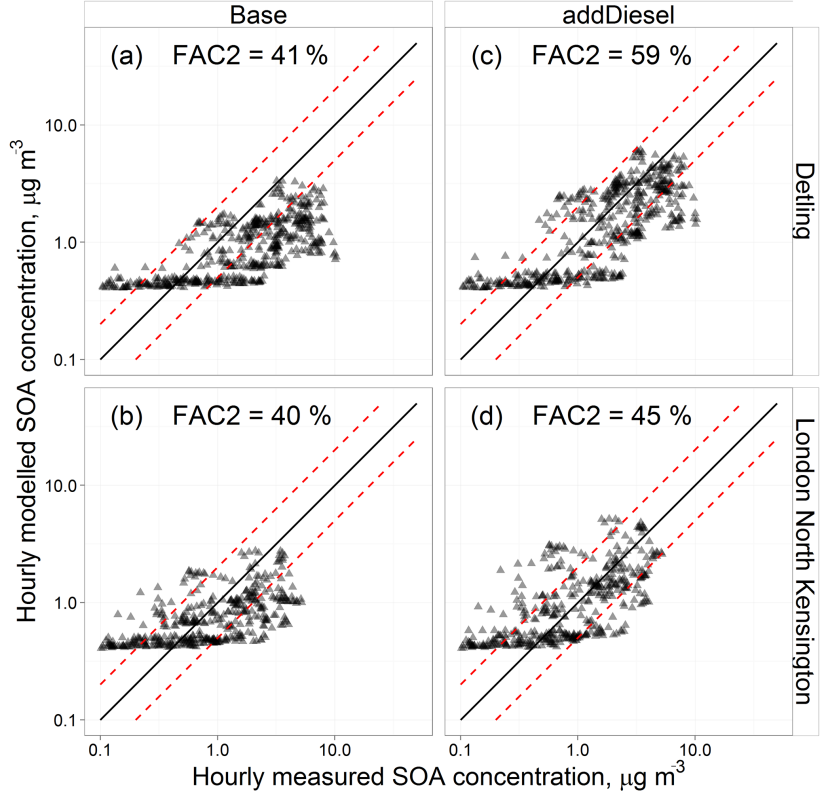

Figure 14. Scatter plots of measured and modelled hourly SOA concentrations during the winter 2012 IOP: (a) Base simulation at the Detling rural background site; (b) Base simulation at the North Kensington urban background site; (c) addDiesel simulation at the Detling rural background site; (d) addDiesel simulation at the North Kensington urban background site. The straight lines are the $2: 1$, $1: 1$, and $1: 2$ lines.

average SOA concentration modelled with the addDiesel run by $33 \%$ ( 2.0 and $1.5 \mu \mathrm{g} \mathrm{m}^{-3}$ with and without these two points, respectively). Their combined influence on the annual average modelled concentration is $8 \%$, which is substantially more than any other points of the annual data set.

For the winter months, modelled concentrations in January are much lower than measurements, whereas in February the timing of several peaks is well reproduced and even overestimated by the addDiesel experiment. Detailed hourly analysis of the SOA concentrations during the winter IOP has been presented in Sect. 3.3. In December, measured SOA concentrations were much lower than in January, and even though the model captures the highest peak, there is some overestimation in the lowest range $\left(<0.5 \mu \mathrm{g} \mathrm{m}^{-3}\right)$.

Figure 17 shows annually and seasonally averaged measured and modelled SOA. The difference between the Base and addDiesel experiments illustrate the impact of missing IVOC emissions from diesel traffic on SOA formation. As was discussed before, and can be seen from Table 4, IVOC precursors from diesel vehicles reduce the NMB by $\sim 30 \%$, which as an annual average is $0.6 \mu \mathrm{g} \mathrm{m}^{-3}$ of additional SOA. Moreover, the 90th percentile of daily averaged SOA concentrations of the addDiesel experiment is $3.8 \mu \mathrm{g} \mathrm{m}^{-3}$ (which is similar to the measured 90th percentile of $3.2 \mu \mathrm{g} \mathrm{m}^{-3}$ ), whereas the 90th percentile of the Base case simulation is $2.2 \mu \mathrm{g} \mathrm{m}^{-3}$. This means that (i), on 36 days
Table 4. Model-measurement comparison statistics for daily SOA at London North Kensington. Autumn is presented with and without the two outliers ( 23 and 24 October $n=91$ and 89, respectively).

\begin{tabular}{|c|c|c|c|c|}
\hline & Base & addDiesel & Base & addDiesel \\
\hline & \multicolumn{2}{|c|}{ spring (MAM) } & \multicolumn{2}{|c|}{ summer (JJA) } \\
\hline$n$ (days) & \multicolumn{2}{|c|}{91} & \multicolumn{2}{|c|}{86} \\
\hline FAC2 & $64 \%$ & $74 \%$ & $60 \%$ & $79 \%$ \\
\hline NMB & $-35 \%$ & $0.1 \%$ & $-34 \%$ & $-5 \%$ \\
\hline NMGE & $45 \%$ & $38 \%$ & $48 \%$ & $39 \%$ \\
\hline$r$ & 0.85 & 0.85 & 0.71 & 0.82 \\
\hline $\mathrm{COE}$ & 0.29 & 0.39 & 0.26 & 0.41 \\
\hline & \multicolumn{2}{|c|}{ autumn (SON) } & \multicolumn{2}{|c|}{ winter (JFD) } \\
\hline$n$ (days) & \multicolumn{2}{|c|}{89} & \multicolumn{2}{|c|}{81} \\
\hline FAC2 & $82 \%$ & $74 \%$ & $70 \%$ & $69 \%$ \\
\hline NMB & $-2 \%$ & $58 \%$ & $-28 \%$ & $6 \%$ \\
\hline NMGE & $52 \%$ & $96 \%$ & $47 \%$ & $61 \%$ \\
\hline$r$ & 0.38 & 0.28 & 0.40 & 0.40 \\
\hline $\mathrm{COE}$ & -0.13 & -1.07 & 0.21 & -0.02 \\
\hline & \multicolumn{2}{|c|}{ autumn (SON) } & & \\
\hline$n$ (days) & \multicolumn{2}{|c|}{91} & & \\
\hline FAC2 & $80 \%$ & $73 \%$ & & \\
\hline NMB & $13 \%$ & $102 \%$ & & \\
\hline NMGE & $63 \%$ & $137 \%$ & & \\
\hline$r$ & 0.58 & 0.54 & & \\
\hline $\mathrm{COE}$ & -0.30 & -1.84 & & \\
\hline
\end{tabular}

of the year, SOA is a notable component of PM (the annual average $\mathrm{PM}_{2.5}$ concentration limit value of the European Union Directive 2008/50/EC is $25 \mu \mathrm{g} \mathrm{m}^{-3}$ ) and that (ii), during those days, the relative contribution to SOA from diesel IVOCs could be greater than $40 \%$ (calculated as the difference between SOA modelled with addDiesel and Base, relative to addDiesel: (addDiesel-Base)/addDiesel). We note that Fig. 17a shows in the addDiesel simulation that the modelled BSOA + Background OA still makes up $53 \%$ of the SOA, as an annual average. This value is based on the assignment of the constant background OA in the model to natural SOA, which is what it is intended to represent. This may have some anthropogenic origin, and more research on the missing (or boundary condition) sources that this background constant represents is needed for accurate attribution of the biogenic vs. anthropogenic relative contributions.

\subsection{OM/OC ratios}

Measured OM/OC ratios for SOA were generally higher than those modelled (1.99-2.34 vs. 1.88-1.97, Table 5). Nevertheless, the measured OM/OC ratio at London North Kensington during the summer IOP was the lowest of the measured range, 1.99 , which is a close match to modelled SOA OM/OC ratio for that period, 1.97. Model performance for spring and summer was shown to be very good, but 

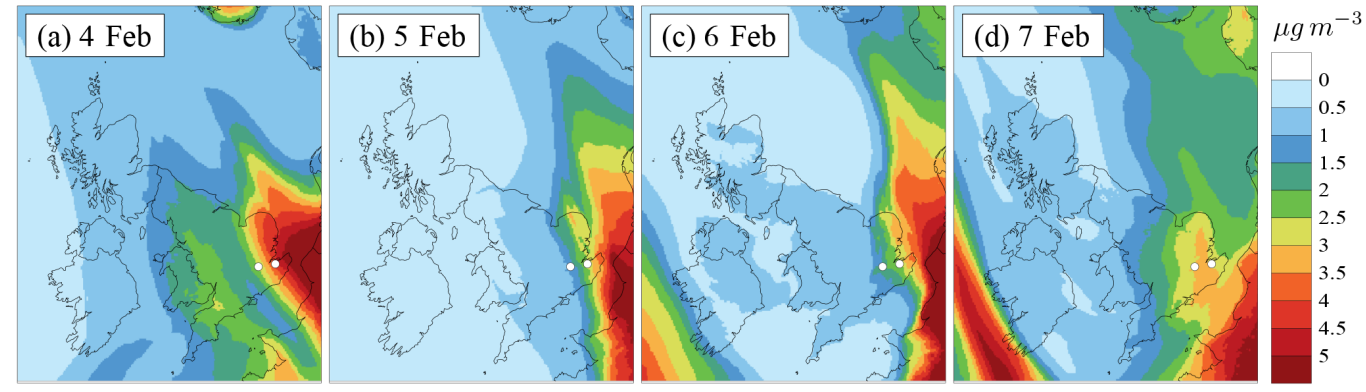

Figure 15. Modelled (addDiesel experiment) daily average concentrations of SOA during the second SOA episode of the winter 2012 IOP. The white circles mark the measurement site locations - left: London North Kensington; right: Detling.

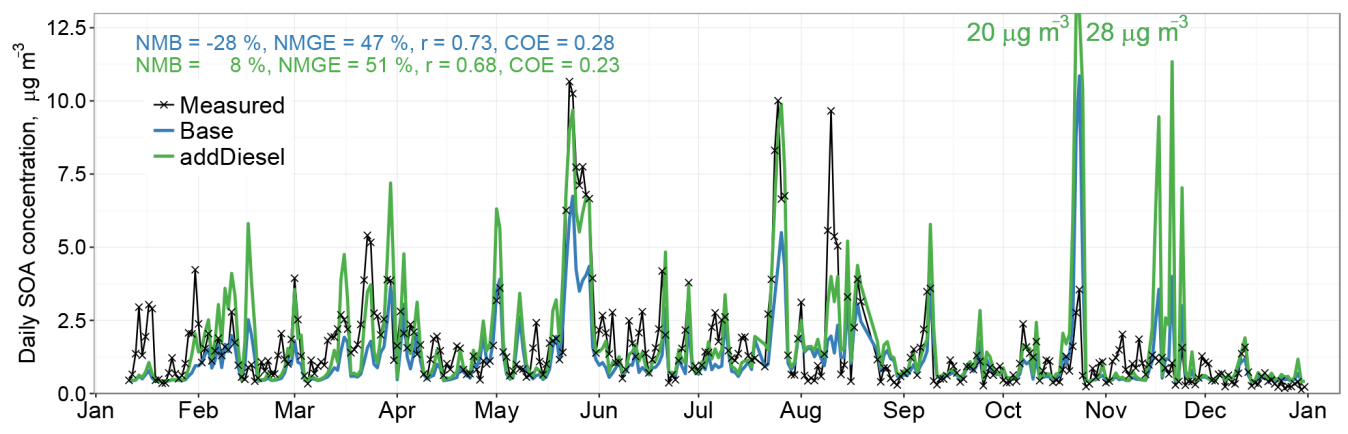

Figure 16. Time series of measured and modelled daily average SOA concentrations at the London North Kensington urban background site. The two outliers (23 and 24 October, included in the plot as labels) are excluded from the model evaluation statistics presented in the plot.

Table 5. Measured and modelled (addDiesel experiment) OM / OC ratios. Site name abbreviations are given in Table 3.

\begin{tabular}{lllcc}
\hline Pollutant & Site & Period & $\begin{array}{c}\text { Meas. } \\
\text { OM/OC }\end{array}$ & $\begin{array}{c}\text { Mod. } \\
\text { OM/OC }\end{array}$ \\
\hline \multirow{4}{*}{ HOA } & NK & winter IOP & 1.25 & \\
& NK & summer IOP & 1.19 & \\
& NK & annual & 1.32 & 1.25 \\
& HAR & summer IOP & 1.31 & \\
& DET & winter IOP & 1.45 & \\
\hline \multirow{5}{*}{ SFOA } & NK & winter IOP & 1.62 & \\
& NK & annual & 1.78 & 1.70 \\
& DET & winter IOP & 1.64 & \\
\hline \multirow{5}{*}{ SOA } & NK & winter IOP & 2.03 & 1.88 \\
& NK & summer IOP & 1.99 & 1.97 \\
& NK & annual & 2.25 & 1.94 \\
& HAR & summer IOP & 2.39 & 1.99 \\
& DET & winter IOP & 2.34 & 1.86 \\
\hline
\end{tabular}

it is possible that the missing SOA precursors in the colder months (from domestic heating) could yield SOA with higher initial OM/OC ratios, thereby increasing the annual average value. Furthermore, wintertime simulations of SOA in Paris by Fountoukis et al. (2016) also showed large underestimations, and they speculated that this could be pointing towards an SOA formation process during periods of low photochemical activity that is currently not simulated in atmospheric chemical transport models.

\subsection{Comparison to the previous $($ IVOCs $=1.5 \times \mathrm{POA})$ approach}

Figure 18 shows the annual average HOA, SFOA, BSOA and background OA (BGND OA), and ASOA concentrations at London North Kensington modelled with different assumptions for additional IVOC emissions. As was explained in Sect. 2.4, for the UK, the addDiesel experiment adds $90 \mathrm{Gg}$ of diesel-related IVOCs proportionally to road transport emissions (SNAP7), whereas the IVOCs $=1.5 \times$ POA approach only adds $5 \mathrm{Gg}$ to SNAP7 and another $26 \mathrm{Gg}$ to other sectors (mainly to SNAP2: residential and non-industrial combustion). Therefore, our approach creates a considerably larger amount of SOA from IVOCs (and only from dieselrelated IVOCs) than the previous method. The 1.5 volPOA experiment was undertaken using the semi-volatile treatment of POA emissions. This means that the modelled ASOA from this experiment also includes aged semi-volatile POA, possibly giving it potential to create more ASOA than the Base or addDiesel experiments (the organic material added to the model in the $1.5 \mathrm{volPOA}$ experiment is $1.0 \times \mathrm{POA}$ (as SVOCs $)+1.5 \times \mathrm{POA}($ IVOCs $)=2.5 \times \mathrm{POA}$ as introduced by Robinson et al. (2007) and Shrivastava et al. (2008)). It 


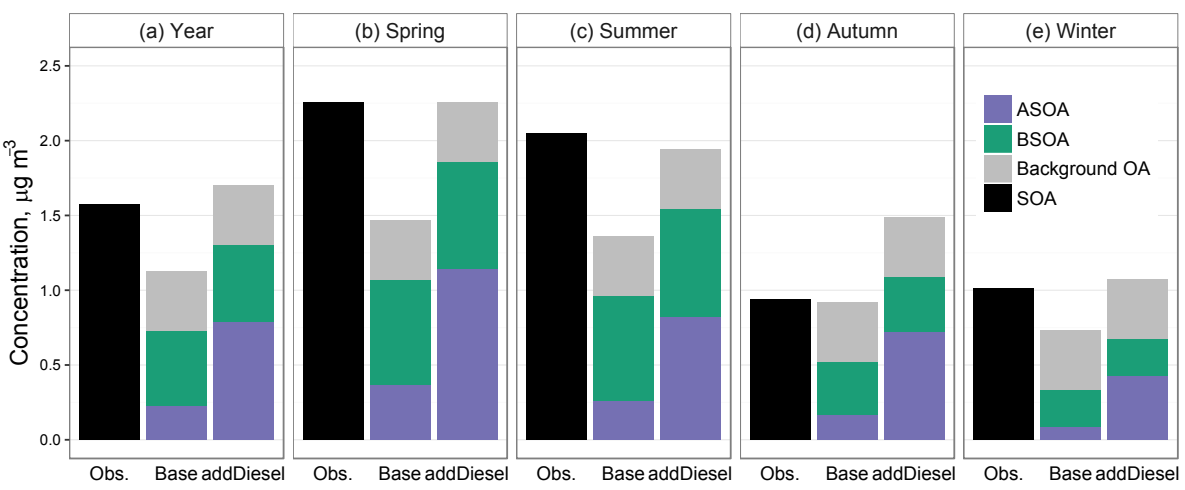

Figure 17. Annually and seasonally averaged measured and modelled concentrations of SOA at the London North Kensington site.

can be seen from Fig. 18a and $b$ that treating POA as semivolatile leads to much lower concentrations than the nonvolatile treatment (which already underestimates measured concentrations of HOA and SFOA by -54 and $-71 \%$, respectively; Fig. 5). This is not surprising given that the semivolatile treatment of POA assigns only $3 \%+6 \%+9 \%$ of the POA to the three lowest volatility bins with saturation concentrations of $0.01,0.1$, and $1 \mu \mathrm{g} \mathrm{m}^{-3}$, respectively (as given in Sect. 2.4). In a study in Mexico City, Shrivastava et al. (2011) revised this treatment by assuming much higher total semi-volatile and intermediate-volatility POA emissions: $7.5 \times$ the inventory emissions of (particulate) POA. This was justified by the fact that their emission factors of POA were derived from measurements at urban background sites, but, following Robinson et al. (2007), two-thirds of POA would have evaporated by then. Recently, Shrivastava et al. (2015) also used this factor of 7.5 in global simulations. Emission factors used in European inventories are, however, taken from tailpipe measurements with concentrations sufficiently high that most of the semi-volatiles should still be reported in the particulate phase. Therefore the further underestimation of HOA and SFOA concentrations with the volatile treatment could be due to a number of issues: (i) a systematic underestimation of emissions, but for a different reason than in Shrivastava et al. (2011); (ii) the volatility of POA is overestimated by Robinson et al. (2007), or (iii) the evaporation of semi-volatile POA emission is too rapid in the model (instantaneous in our set-up).

Figure $18 \mathrm{c}$ shows that the lower HOA and SFOA concentrations lead to a very small negative change for the absorptive partitioning of BSOA. Finally, it can be seen from the annual average concentrations of ASOA in Fig. 18d that including aged SVOCs and IVOCs in the simulation doubles the modelled ASOA concentration compared to the Base case scenario (ASOA from officially reported anthropogenic VOCs) but that the ASOA in our 1.5volPOA experiment is still much lower than simulated with our addDiesel experiment.

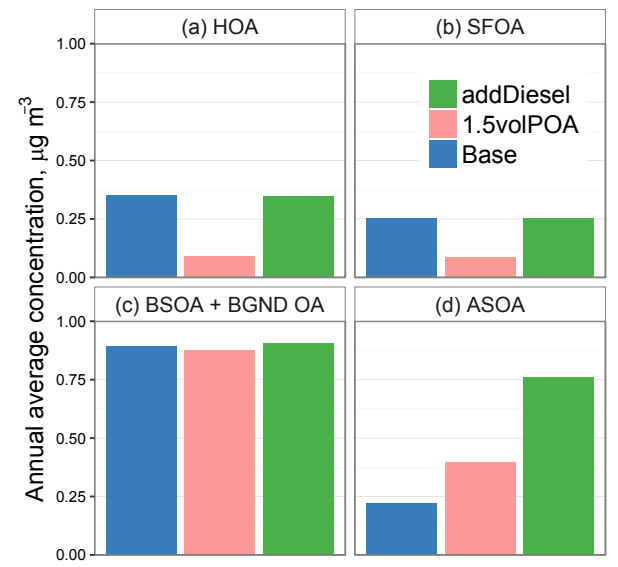

Figure 18. Simulated annual and seasonal average concentrations of OA components (BGND OA stands for background OA) for the London North Kensington site of three different model experiments: Base - all emissions as in officially reported emissions inventories, and POA is treated as non-volatile; 1.5 volPOA - semi-volatile treatment of POA + IVOC emissions added as $1.5 \times$ POA; addDiesel Base + IVOC emissions from diesel traffic added proportionally to VOC emissions from the on-road traffic source sector (SNAP7). The last two additions are as described in the main text.

\section{Discussion}

We show that $\sim 30 \%$ of SOA in London could be produced from completely new estimates of diesel-related IVOC emissions that are not currently included in the emissions inventories. This is one of a very few studies where IVOC emissions are added proportionally to NMVOC emissions (as opposed to addition proportionally to POA emissions). Moreover, previous studies have added IVOCs proportionally to POA from all sources, whereas this study focuses specifically on the impact of diesel IVOCs from on-road traffic emissions (IVOCs $=2.3 \times$ SNAP7 VOCs). There is reason to believe that higher-volatility VOCs are better represented in current emissions inventories than the emissions of PM. Also, the official inventories do not provide the individual contribu- 
tion of POA to total PM. Therefore, the addition of IVOCs proportionally to NMVOCs may be better constrained than the POA-based approach used in studies so far. The additional emissions are also tied directly to the relevant emission source category.

There are several possible uncertainties in our estimate of additional IVOCs, and subsequent SOA production and ageing. As a first approximation, we added IVOCs to each European country based on our measurements in London. This was justified as the diesel usage in the UK is similar to the European average. Furthermore, different European countries might be using different emissions factors for their estimates of NMVOCs from petrol and diesel or have a different average fleet age than the UK. It should be noted that two of the most populous countries in Europe - France and Germany - both have a higher diesel penetration than the UK , and therefore for western central Europe our addition is rather conservative.

It was seen from the hourly profiles at the London North Kensington site during the summer IOP (Fig. 9b) that both the model and the measurements exhibit a small diurnal cycle (peaking in the afternoon). Even though somewhat counterintuitive (as most of the SOA chemistry is photochemically driven through reaction with the $\mathrm{OH}$ radical), an absence of a strong diurnal cycle of SOA has been seen in many European studies (Zhang et al., 2013; Fountoukis et al., 2014; Young et al., 2015a). A relatively small daytime increase in SOA could be explained by the expansion of the boundary layer height (Xu et al., 2015), as well as by contributions from long-range transport. PMF measurements of SOA in Mexico City, on the other hand, revealed a very strong diurnal cycle, peaking around midday (Shrivastava et al., 2011). The fact that during the summer IOP our addDiesel experiment exhibits a slightly stronger diurnal cycle than the measurements (with daytime values slightly overestimated and nighttime underestimated) indicates that the SOA yields could be too high. We assumed an SOA density of $1.5 \mathrm{~g} \mathrm{~cm}^{-3}$ and increased the yields linearly, as has been done in all other ACTM studies. Actually, increasing the assumed density of SOA from the unit value $\left(1 \mathrm{~g} \mathrm{~cm}^{-3}\right)$ changes the total $\mathrm{C}_{\mathrm{OA}}$ (condensed-phase OA) on the Odum mass yield plots (Odum et al., 1996) used to derive the yields from the chamber experiment. Therefore, increasing the yields linearly is not exactly correct (N. M. Donahue, personal communication, 2015) and further studies and refinement into the calculation of SOA yields and density would be beneficial.

We use an ageing rate of $4.0 \times 10^{-12} \mathrm{~cm}^{3}$ molecule ${ }^{-1} \mathrm{~s}^{-1}$ for both ASOA and BSOA (Lane et al., 2008). This is slower than has been used in some other studies (for example, Tsimpidi et al., 2010, use $4.0 \times 10^{-11} \mathrm{~cm}^{3}$ molecule ${ }^{-1} \mathrm{~s}^{-1}$, which is 10 times faster, and Fountoukis et al., 2011, use $1.0 \times 10^{-11} \mathrm{~cm}^{3}$ molecule ${ }^{-1} \mathrm{~s}^{-1}$, which is 2.5 times faster). A combination of lower initial SOA yields but slightly higher ageing rates could possibly flatten the diurnal cycle of our modelled SOA, matching the measurements better. There- fore, an improvement for the detailed, hourly evolution could be achieved by a sensitivity study of these yields and ageing rates. This does not, however, change the main scope and results of this paper which illustrate the relative impact of the diesel IVOCs on SOA formation.

In the current set-up of the EMEP model, only two PM size fractions are simulated $-\mathrm{PM}_{2.5}$ and $\mathrm{PM}_{2.5}-10$ - because only two fractions are included in the emissions inventories for PM used in this study. Even though on an annual basis $90 \%$ of $\mathrm{OC}_{2.5}$ is in the submicron $\left(\mathrm{OC}_{1}\right)$ range (Sect. 2.6), the comparison between a modelled $\mathrm{OC}_{2.5}$ and a measured $\mathrm{OC}_{1}$ could be introducing larger errors during specific days or hours. Therefore, as AMS measurements become more prevalent, emissions inventories should be reported for all three size classes, $\mathrm{PM}_{1}, \mathrm{PM}_{1-2.5}$, and $\mathrm{PM}_{2.5-10}$. This would allow the model to partition SOA into the corresponding fractions, making the direct comparison of modelled $\mathrm{SOA}_{1}$ to measured $\mathrm{SOA}_{1}$ possible.

We showed that treating POA as semi-volatile and letting it evaporate led to a great underestimation of HOA and SFOA concentrations compared to measurements at the London North Kensington urban background site. As has been highlighted by a number studies before us (listed in the Introduction), we would also emphasize that a major source of uncertainty in OA modelling is the volatility of primary emissions, an issue that is currently not addressed by official emissions inventories. In our experiment of semi-volatile POA (denoted 1.5volPOA), IVOCs were included from all source sectors. This experiment simulated substantially less ASOA than our addition of IVOCs associated with just the traffic source sector. This means that a combination of the POAbased IVOCs and our addition of diesel IVOCs proportional to NMVOCs would not create a substantial overestimation of SOA concentrations compared to measurements. Nevertheless, further modelling studies (including different assumptions regarding ageing rates, fragmentation, and yields) as well as more measurements of IVOC emissions from different sources are clearly necessary.

In the evaluation of modelled and measured SOA, it was shown that some of the uncertainties in the modelled concentrations are caused by errors in modelled wind vectors. Nevertheless, the underlying meteorological model works well (as demonstrated by comparisons of different pollutants for the whole calendar year), and overall the errors caused by meteorology are believed to be relatively smaller than those introduced by emissions (amount, volatility, composition), or SOA yields and ageing rates.

\section{Conclusions}

This study presents annual time series of new high-resolution simulations of SOA formation over the UK (using the EMEP4UK Eulerian atmospheric chemical transport model) that include diesel-related IVOC emissions not currently in- 
cluded in the emissions inventory. The derivation of the magnitude of these additional emissions of SOA precursors and the evaluation of the model simulated SOA were both based on measurements made during the Clean Air for London (ClearfLo) campaign in 2012. The IVOC emissions were added in proportion to the VOC emissions from the specifically relevant on-road traffic source, in contrast to previous studies that have added IVOCs proportionally to primary organic aerosol (POA) emissions from all POA sources. Modelled concentrations of SOA were compared with positive matrix factorization (PMF) analyses of aerosol mass spectrometer (AMS) measurements at a central London urban background location (North Kensington) and at the Detling and Harwell rural background locations outside of London.

The model performance in comparison to relatively more well-known components of air pollution, such as $\mathrm{NO}_{x}, \mathrm{O}_{3}$, and secondary inorganic aerosol, was shown to be very good, providing confidence in the prediction skill of the ACTM system used. Modelled concentrations of SOA were evaluated in four groups: (i) hourly comparison during a summer IOP (intensive observation period), (ii) hourly comparison during a winter IOP, (iii) daily comparison for a full calendar year (including seasonal statistics), and (iv) comparison of $\mathrm{OM} / \mathrm{OC}$ ratios of all apportioned OA components. To our knowledge, this is the first study where modelled OA components are compared with a year-long data set of PMFapportioned AMS measurements.

During the period of concurrent measurements at all locations, SOA concentrations at the Detling rural background location were greater than at the central London location. The model showed that this was caused by an intense pollution plume with a strong gradient of SOA from mainland Europe passing over the rural location and demonstrates how short periods of measurements can give a different picture compared with longer-term measurements, as well as the value of atmospheric chemistry transport modelling for supporting the interpretation of measurements taken at different sites or for short durations.

The model simulations show that these estimates of dieselrelated IVOCs could explain on average $\sim 30 \%$ of the annual SOA in and around London. The 90th percentile of modelled daily SOA concentrations at the urban background site for the whole year was $3.8 \mathrm{\mu g} \mathrm{m}^{-3}$, and the influence of missing diesel-related IVOC precursors was even greater on high percentile SOA days than its contribution to annual average SOA. The magnitudes of these contributions to SOA provide strong additional support for the need to undertake further refinement of the amount and speciation of these precursor emissions for inclusion in official emissions inventories.

\section{Data availability}

Processed measurement data used in this study are available through the ClearfLo project archive at the British Atmospheric Data Centre (http://badc.nerc.ac.uk/browse/badc/ clearflo). The model data (input, code, relevant output) are archived at the University of Edinburgh, and Centre for Ecology\&Hydrology and are available on request.

Acknowledgements. The authors acknowledge the UK Department for Environment, Food and Rural Affairs (Defra) and the Devolved Administrations for several projects: development of the EMEP4UK model (AQ0727); access to the AURN data, which were obtained from uk-air.defra.gov.uk and are subject to Crown 2014 copyright, Defra, licensed under the Open Government Licence (OGL); and partial support for the aerosol measurements. Partial support for the EMEP4UK modelling from the European Commission FP7 ECLAIRE project is gratefully acknowledged. This work was supported in part by the UK Natural Environment Research Council (NERC) ClearfLo project (grant ref. NE/H008136/1). Riinu Ots was supported by a PhD studentship (University of Edinburgh and NERC-CEH contract 587/NEC03805). Dominique E. Young was supported by a NERC PhD studentship (ref. NE/I528142/1). Rachel E. Dunmore was supported by a NERC PhD studentship (ref. NE/J500197/1). Nga L. Ng, Lu Xu, Leah R. Williams, and Scott C. Herndon were supported by the US Department of Energy (grant no. DE-SC000602). The authors would like to thank David Simpson for helpful advice about the EMEP model.

NCAR command language (NCL) was used to produce the maps (NCAR, 2015), and R, openair, and ggplot2 were used for the analysis and all other plots (R Core Team, 2014; Carslaw and Ropkins, 2012; Wickham, 2009).

Edited by: M. Kanakidou

\section{References}

Aiken, A. C., DeCarlo, P. F., Kroll, J. H., Worsnop, D. R., Huffman, J. A., Docherty, K. S., Ulbrich, I. M., Mohr, C., Kimmel, J. R., Sueper, D., Sun, Y., Zhang, Q., Trimborn, A., Northway, M., Ziemann, P. J., Canagaratna, M. R., Onasch, T. B., Alfarra, M. R., Prevot, A. S. H., Dommen, J., Duplissy, J., Metzger, A., Baltensperger, U., and Jimenez, J. L.: O/C and OM/OC Ratios of Primary, Secondary, and Ambient Organic Aerosols with HighResolution Time-of-Flight Aerosol Mass Spectrometry, Environ. Sci. Technol., 42, 4478-4485, doi:10.1021/es703009q, 2008.

Aksoyoglu, S., Keller, J., Barmpadimos, I., Oderbolz, D., Lanz, V. A., Prévôt, A. S. H., and Baltensperger, U.: Aerosol modelling in Europe with a focus on Switzerland during summer and winter episodes, Atmos. Chem. Phys., 11, 7355-7373, doi:10.5194/acp11-7355-2011, 2011.

Allan, J. D., Williams, P. I., Morgan, W. T., Martin, C. L., Flynn, M. J., Lee, J., Nemitz, E., Phillips, G. J., Gallagher, M. W., and Coe, H.: Contributions from transport, solid fuel burning and cooking to primary organic aerosols in two UK cities, Atmos. Chem. Phys., 10, 647-668, doi:10.5194/acp-10-647-2010, 2010.

AQEG: Report: Fine Particulate Matter $\left(\mathrm{PM}_{2.5}\right)$ in the United - Defra, UK, http://uk-air.defra.gov.uk/library/reports?report_id=727 (last access: 24 May 2016), 2012. 
Atkinson, R. and Arey, J.: Atmospheric Degradation of Volatile Organic Compounds, Chem. Rev., 103, 4605-4638, doi:10.1021/cr0206420, 2003.

Bahreini, R., Middlebrook, A. M., de Gouw, J. A., Warneke, C., Trainer, M., Brock, C. A., Stark, H., Brown, S. S., Dube, W. P., Gilman, J. B., Hall, K., Holloway, J. S., Kuster, W. C., Perring, A. E., Prevot, A. S. H., Schwarz, J. P., Spackman, J. R., Szidat, S., Wagner, N. L., Weber, R. J., Zotter, P., and Parrish, D. D.: Gasoline emissions dominate over diesel in formation of secondary organic aerosol mass, Geophys. Res. Lett., 39, L06805, doi:10.1029/2011GL050718, 2012.

Berg, A. R., Heald, C. L., Huff Hartz, K. E., Hallar, A. G., Meddens, A. J. H., Hicke, J. A., Lamarque, J., and Tilmes, S.: The impact of bark beetle infestations on monoterpene emissions and secondary organic aerosol formation in western North America, Atmos. Chem. Phys., 13, 3149-3161, doi:10.5194/acp-13-31492013, 2013.

Bergström, R., Denier van der Gon, H. A. C., Prévôt, A. S., Yttri, K. E., and Simpson, D.: Modelling of organic aerosols over Europe (2002-2007) using a volatility basis set (VBS) framework: application of different assumptions regarding the formation of secondary organic aerosol, Atmos. Chem. Phys., 12, 8499-8527, doi:10.5194/acp-12-8499-2012, 2012.

Bergström, R., Hallquist, M., Simpson, D., Wildt, J., and Mentel, T. F.: Biotic stress: a significant contributor to organic aerosol in Europe?, Atmos. Chem. Phys., 14, 13643-13660, doi:10.5194/acp14-13643-2014, 2014.

Binkowski, F. S. and Shankar, U.: The Regional Particulate Matter Model: 1. Model description and preliminary results, J. Geophys. Res.-Atmos., 100, 26191-26209, doi:10.1029/95JD02093, 1995.

Bohnenstengel, S. I., Belcher, S. E., Aiken, A., Allan, J. D., Allen, G., Bacak, A., Bannan, T. J., Barlow, J. F., Beddows, D. C. S., Bloss, W. J., Booth, A. M., Chemel, C., Coceal, O., Di Marco, C. F., Dubey, M. K., Faloon, K. H., Fleming, Z. L., Furger, M., Gietl, J. K., Graves, R. R., Green, D. C., Grimmond, C. S. B., Halios, C. H., Hamilton, J. F., Harrison, R. M., Heal, M. R., Heard, D. E., Helfter, C., Herndon, S. C., Holmes, R. E., Hopkins, J. R., Jones, A. M., Kelly, F. J., Kotthaus, S., Langford, B., Lee, J. D., Leigh, R. J., Lewis, A. C., Lidster, R. T., LopezHilfiker, F. D., McQuaid, J. B., Mohr, C., Monks, P. S., Nemitz, E., Ng, N. L., Percival, C. J., Prévôt, A. S. H., Ricketts, H. M. A., Sokhi, R., Stone, D., Thornton, J. A., Tremper, A. H., Valach, A. C., Visser, S., Whalley, L. K., Williams, L. R., Xu, L., Young, D. E., and Zotter, P.: Meteorology, Air Quality, and Health in London: The ClearfLo Project, B. Am. Meteorol. Soc., 96, 779804, doi:10.1175/BAMS-D-12-00245.1, 2014.

Cames, M. and Helmers, E.: Critical evaluation of the European diesel car boom - global comparison, environmental effects and various national strategies, Environ. Sci. Europe, 25, 1-22, doi:10.1186/2190-4715-25-15, 2013.

Canagaratna, M. R., Jayne, J., Jimenez, J., Allan, J., Alfarra, M., Zhang, Q., Onasch, T., Drewnick, F., Coe, H., Middlebrook, A., Delia, A., Williams, L., Trimborn, A., Northway, M., DeCarlo, P., Kolb, C., Davidovits, P., and Worsnop, D.: Chemical and microphysical characterization of ambient aerosols with the aerodyne aerosol mass spectrometer, Mass Spectrom. Rev., 26, 185-222, doi:10.1002/mas.20115, 2007.

Canagaratna, M. R., Jimenez, J. L., Kroll, J. H., Chen, Q., Kessler, S. H., Massoli, P., Hildebrandt Ruiz, L., Fortner, E., Williams, L.
R., Wilson, K. R., Surratt, J. D., Donahue, N. M., Jayne, J. T., and Worsnop, D. R.: Elemental ratio measurements of organic compounds using aerosol mass spectrometry: characterization, improved calibration, and implications, Atmos. Chem. Phys., 15, 253-272, doi:10.5194/acp-15-253-2015, 2015.

Carslaw, D. C. and Ropkins, K.: openair - An R package for air quality data analysis, Environ. Model. Softw., 27-28, 52-61, doi:10.1016/j.envsoft.2011.09.008, 2012.

CEIP: WebDab EMEP database: Emissions as used in EMEP models, http://www.ceip.at/ms/ceip_home1/ceip_home/webdab_ emepdatabase/, last access: 15 July 2015.

Chhabra, P. S., Flagan, R. C., and Seinfeld, J. H.: Elemental analysis of chamber organic aerosol using an aerodyne high-resolution aerosol mass spectrometer, Atmos. Chem. Phys., 10, 4111-4131, doi:10.5194/acp-10-4111-2010, 2010.

Crilley, L. R., Bloss, W. J., Yin, J., Beddows, D. C. S., Harrison, R. M., Allan, J. D., Young, D. E., Flynn, M., Williams, P., Zotter, P., Prevot, A. S. H., Heal, M. R., Barlow, J. F., Halios, C. H., Lee, J. D., Szidat, S., and Mohr, C.: Sources and contributions of wood smoke during winter in London: assessing local and regional influences, Atmos. Chem. Phys., 15, 3149-3171, doi:10.5194/acp15-3149-2015, 2015.

Denier van der Gon, H. A. C., Bergström, R., Fountoukis, C., Johansson, C., Pandis, S. N., Simpson, D., and Visschedijk, A J. H.: Particulate emissions from residential wood combustion in Europe - revised estimates and an evaluation, Atmos. Chem. Phys., 15, 6503-6519, doi:10.5194/acp-15-6503-2015, 2015.

Di Marco, C. F., Nemitz, E., Twigg, M. M., Langford, B., Lingard, J. J. N., and Ritchie, S.: Chemical characterisation of the aerosol at a background site in southern England with emphasis on the organic fraction and nitrogen compounds, in preparation, 2016.

Donahue, N. M., Robinson, A. L., Stanier, C. O., and Pandis, S. N.: Coupled Partitioning, Dilution, and Chemical Aging of Semivolatile Organics, Environ. Sci. Technol., 40, 2635-2643, doi:10.1021/es052297c, 2006.

Donahue, N. M., Epstein, S. A., Pandis, S. N., and Robinson, A. L.: A two-dimensional volatility basis set: 1. organic-aerosol mixing thermodynamics, Atmos. Chem. Phys., 11, 3303-3318, doi:10.5194/acp-11-3303-2011, 2011.

Donahue, N. M., Kroll, J. H., Pandis, S. N., and Robinson, A. L.: A two-dimensional volatility basis set - Part 2: Diagnostics of organic-aerosol evolution, Atmos. Chem. Phys., 12, 615-634, doi:10.5194/acp-12-615-2012, 2012.

Donahue, N. M., Robinson, A. L., Trump, E. R., Riipinen, I., and Kroll, J. H.: Volatility and Aging of Atmospheric Organic Aerosol, in: Atmospheric and Aerosol Chemistry, no. 339 in Topics in Current Chemistry, edited by: McNeill, V. F. and Ariya, P. A., Springer, Berlin, Heidelberg, 97-143, 2014.

Dunmore, R. E., Hopkins, J. R., Lidster, R. T., Lee, J. D., Evans, M. J., Rickard, A. R., Lewis, A. C., and Hamilton, J. F.: Diesel-related hydrocarbons can dominate gas phase reactive carbon in megacities, Atmos. Chem. Phys., 15, 9983-9996, doi:10.5194/acp-15-9983-2015, 2015.

EEA: Dieselisation in the European Economic Area, Tech. rep., http://www.eea.europa.eu/data-and-maps/figures/ dieselisation-in-the-eea (last access: 24 May 2016), 2010.

EEA: EMEP/EEA air pollutant emission inventory guidebook - 2013, http://www.eea.europa.eu/publications/ emep-eea-guidebook-2013 (last access: 24 May 2016), 2013. 
Entec: UK ship emissions inventory, final report, Tech. rep., crown copyright, http://uk-air.defra.gov.uk/assets/documents/reports/ cat15/1012131459_21897_Final_Report_291110.pdf, (last access: 24 May 2016), 2010.

Exxon Mobil: The Outlook for Energy: A view to 2040, Tech. rep., Exxon Mobil Corporation, Texas, available at: http: //cdn.exxonmobil.com/ /media/global/files/outlook-for-energy/ 2015-outlook-for-energy_print-resolution.pdf (last access: 24 May 2016), 2014.

Fountoukis, C., Racherla, P. N., Denier van der Gon, H. A. C., Polymeneas, P., Charalampidis, P. E., Pilinis, C., Wiedensohler, A., Dall'Osto, M., O'Dowd, C., and Pandis, S. N.: Evaluation of a three-dimensional chemical transport model (PMCAMx) in the European domain during the EUCAARI May 2008 campaign, Atmos. Chem. Phys., 11, 10331-10347, doi:10.5194/acp11-10331-2011, 2011.

Fountoukis, C., Megaritis, A. G., Skyllakou, K., Charalampidis, P. E., Pilinis, C., Denier van der Gon, H. A. C., Crippa, M., Canonaco, F., Mohr, C., Prévôt, A. S. H., Allan, J. D., Poulain, L., Petäjä, T., Tiitta, P., Carbone, S., Kiendler-Scharr, A., Nemitz, E., O'Dowd, C., Swietlicki, E., and Pandis, S. N.: Organic aerosol concentration and composition over Europe: insights from comparison of regional model predictions with aerosol mass spectrometer factor analysis, Atmos. Chem. Phys., 14, 9061-9076, doi:10.5194/acp-14-9061-2014, 2014

Fountoukis, C., Megaritis, A. G., Skyllakou, K., Charalampidis, P. E., Denier van der Gon, H. A. C., Crippa, M., Prévôt, A. S. H., Fachinger, F., Wiedensohler, A., Pilinis, C., and Pandis, S. N.: Simulating the formation of carbonaceous aerosol in a European Megacity (Paris) during the MEGAPOLI summer and winter campaigns, Atmos. Chem. Phys., 16, 3727-3741, doi:10.5194/acp-16-3727-2016, 2016

Fuzzi, S., Andreae, M. O., Huebert, B. J., Kulmala, M., Bond, T. C., Boy, M., Doherty, S. J., Guenther, A., Kanakidou, M., Kawamura, K., Kerminen, V., Lohmann, U., Russell, L. M., and Pöschl, U.: Critical assessment of the current state of scientific knowledge, terminology, and research needs concerning the role of organic aerosols in the atmosphere, climate, and global change, Atmos. Chem. Phys., 6, 2017-2038, doi:10.5194/acp-62017-2006, 2006.

Genberg, J., Hyder, M., Stenström, K., Bergström, R., Simpson, D., Fors, E. O., Jönsson, J. R., and Swietlicki, E.: Source apportionment of carbonaceous aerosol in southern Sweden, Atmos. Chem. Phys., 11, 11387-11400, doi:10.5194/acp-1111387-2011, 2011.

Gentner, D. R., Isaacman, G., Worton, D. R., Chan, A. W. H., Dallmann, T. R., Davis, L., Liu, S., Day, D. A., Russell, L. M., Wilson, K. R., Weber, R., Guha, A., Harley, R. A., and Goldstein, A. H.: Elucidating secondary organic aerosol from diesel and gasoline vehicles through detailed characterization of organic carbon emissions, P. Natl. Acad. Sci. USA, 109, 18318-18323, doi:10.1073/pnas.1212272109, 2012.

Goldstein, A. H. and Galbally, I. E.: Known and Unexplored Organic Constituents in the Earth's Atmosphere, Enviro. Sci. Technol., 41, 1514-1521, doi:10.1021/es072476p, 2007.

Hallquist, M., Wenger, J. C., Baltensperger, U., Rudich, Y., Simpson, D., Claeys, M., Dommen, J., Donahue, N. M., George, C., Goldstein, A. H., Hamilton, J. F., Herrmann, H., Hoffmann, T., Iinuma, Y., Jang, M., Jenkin, M. E., Jimenez, J. L., Kiendler-
Scharr, A., Maenhaut, W., McFiggans, G., Mentel, T. F., Monod, A., Prévôt, A. S. ., Seinfeld, J. H., Surratt, J. D., Szmigielski, R., and Wildt, J.: The formation, properties and impact of secondary organic aerosol: current and emerging issues, Atmos. Chem. Phys., 9, 5155-5236, doi:10.5194/acp-9-5155-2009, 2009.

Harrison, R. M. and Yin, J.: Sources and processes affecting carbonaceous aerosol in central England, Atmos. Environ., 42, 1413-1423, doi:10.1016/j.atmosenv.2007.11.004, 2008.

Heal, M. R., Kumar, P., and Harrison, R. M.: Particles, air quality, policy and health, Chem. Soc. Rev., 41, 6606-6630, doi:10.1039/c2cs35076a, 2012.

Hodzic, A., Jimenez, J. L., Madronich, S., Canagaratna, M. R., DeCarlo, P. F., Kleinman, L., and Fast, J.: Modeling organic aerosols in a megacity: potential contribution of semi-volatile and intermediate volatility primary organic compounds to secondary organic aerosol formation, Atmos. Chem. Phys., 10, 5491-5514, doi:10.5194/acp-10-5491-2010, 2010.

Jathar, S. H., Farina, S. C., Robinson, A. L., and Adams, P. J.: The influence of semi-volatile and reactive primary emissions on the abundance and properties of global organic aerosol, Atmos. Chem. Phys., 11, 7727-7746, doi:10.5194/acp-11-77272011, 2011.

Jathar, S. H., Gordon, T. D., Hennigan, C. J., Pye, H. O. T., Pouliot, G., Adams, P. J., Donahue, N. M., and Robinson, A. L.: Unspeciated organic emissions from combustion sources and their influence on the secondary organic aerosol budget in the United States, P. Natl. Acad. Sci. USA, 111, 10473-10478, doi:10.1073/pnas.1323740111, 2014.

Jimenez, J. L., Canagaratna, M. R., Donahue, N. M., Prevot, A. S., Zhang, Q., Kroll, J. H., DeCarlo, P. F., Allan, J. D., Coe, H., Ng, N. L., Aiken, A. C., Docherty, K. S., Ulbrich, I. M., Grieshop, A. P., Robinson, A. L., Duplissy, J., Smith, J. D., Wilson, K. R., Lanz, A. V., Hueglin, C., Sun, Y. L., Tian, J., Laaksonen, A., Raatikainen, T., Rautiainen, J., Vaattovaara, P., Ehn, M., Kulmala, M., Tomlinson, J. M., Collins, D. R., Cubison, M. J., Dunlea, E. J., Huffman, J. A., Onasch, T. B., Alfarra, M. R., Williams, P. I., Bower, K., Kondo, Y., Schneider, J., Drewnick, F., Borrmann, S., Weimer, S., Demerjian, K., Salcedo, D., Cottrell, L., Griffin, R., Takami, A., Miyoshi, T., Hatakeyama, S., Shimono, A., Sun, J. Y., Zhang, Y. M., Dzepina, K., Kimmel, J. R., Sueper, D., Jayne, J. T., Herndon, S. C., Trimborn, A. M., Williams, L. R., Wood, E. C., Middlebrook, A. M., Kolb, C. E., Baltensperger, U., and Worsnop, D. R.: Evolution of Organic Aerosols in the Atmosphere, Science, 326, 1525-1529, doi:10.1126/science.1180353, 2009.

Koo, B., Knipping, E., and Yarwood, G.: 1.5-Dimensional volatility basis set approach for modeling organic aerosol in CAMx and CMAQ, Atmos. Environ., 95, 158-164, doi:10.1016/j.atmosenv.2014.06.031, 2014.

Kuenen, J. J. P., Visschedijk, A. J. H., Jozwicka, M., and Denier van der Gon, H. A. C.: TNO-MACC_II emission inventory; a multiyear (2003-2009) consistent high-resolution European emission inventory for air quality modelling, Atmos. Chem. Phys., 14, 10963-10976, doi:10.5194/acp-14-10963-2014, 2014.

Lane, T. E., Donahue, N. M., and Pandis, S. N.: Simulating secondary organic aerosol formation using the volatility basis-set approach in a chemical transport model, Atmos. Environ., 42, 7439-7451, doi:10.1016/j.atmosenv.2008.06.026, 2008. 
Lanz, V. A., Prévôt, A. S. H., Alfarra, M. R., Weimer, S., Mohr, C., DeCarlo, P. F., Gianini, M. F. D., Hueglin, C., Schneider, J., Favez, O., D’Anna, B., George, C., and Baltensperger, U.: Characterization of aerosol chemical composition with aerosol mass spectrometry in Central Europe: an overview, Atmos. Chem. Phys., 10, 10453-10471, doi:10.5194/acp-10-10453-2010, 2010.

Legates, D. R. and McCabe, G. J.: A refined index of model performance: a rejoinder, Int. J. Climatol., 33, 1053-1056, doi:10.1002/joc.3487, 2013.

Murphy, B. N. and Pandis, S. N.: Simulating the Formation of Semivolatile Primary and Secondary Organic Aerosol in a Regional Chemical Transport Model, Environ. Sci. Technol., 43, 4722-4728, doi:10.1021/Es803168a, 2009.

NAEI: UK Emission Mapping Methodology 2009, http://uk-air. defra.gov.uk/assets/documents/reports/cat07/1403100909_

UK_Emission_Mapping_Methodology_2011-Issue_1.pdf (last access: 24 May 2016), 2013.

NCAR: A Description of the Advanced Research WRF Version 3, Tech. rep., http://www2.mmm.ucar.edu/wrf/users/docs/arw_v3. pdf (last access: 24 May 2016), 2008.

NCAR: The NCAR Command Language (Version 6.3.0) [Software], UCAR/NCAR/CISL/TDD, Boulder, Colorado, doi:10.5065/D6WD3XH5, 2015.

NCEP: NCEP FNL Operational Model Global Tropospheric Analyses, continuing from July 1999, Research Data Archive at the National Center for Atmospheric Research, Computational and Information Systems Laboratory, Boulder, CO, doi:10.5065/D6M043C6, 2000.

Ng, N. L., Canagaratna, M. R., Zhang, Q., Jimenez, J. L., Tian, J., Ulbrich, I. M., Kroll, J. H., Docherty, K. S., Chhabra, P. S., Bahreini, R., Murphhy, S. M., Seinfeld, J. H., Hildebrandt, L., Donahue, N. M., DeCarlo, P. F., Lanz, V. A., Prévôt, A. S. H., Dinar, E., Rudich, Y., and Worsnop, D. R.: Organic aerosol components observed in Northern Hemispheric datasets from Aerosol Mass Spectrometry, Atmos. Chem. Phys., 10, 46254641, doi:10.5194/acp-10-4625-2010, 2010.

Ng, N. L., Canagaratna, M. R., Jimenez, J. L., Zhang, Q., Ulbrich, I. M., and Worsnop, D. R.: Real-Time Methods for Estimating Organic Component Mass Concentrations from Aerosol Mass Spectrometer Data, Environ. Sci. Technol., 45, 910-916, doi:10.1021/es102951k, 2011.

Odum, J. R., Hoffmann, T., Bowman, F., Collins, D., Flagan, R. C., and Seinfeld, J. H.: Gas/Particle Partitioning and Secondary Organic Aerosol Yields, Environ. Sci. Technol., 30, 2580-2585, doi:10.1021/es950943+, 1996.

Paatero, P.: Least squares formulation of robust non-negative factor analysis, Chemometr. Intel. Labor. Syst., 37, 23-35, doi:10.1016/S0169-7439(96)00044-5, 1997.

Paatero, P. and Tapper, U.: Positive matrix factorization: A non-negative factor model with optimal utilization of error estimates of data values, Environmetrics, 5, 111-126, doi:10.1002/env.3170050203, 1994.

Pan, X., Chin, M., Gautam, R., Bian, H., Kim, D., Colarco, P. R., Diehl, T. L., Takemura, T., Pozzoli, L., Tsigaridis, K., Bauer, S., and Bellouin, N.: A multi-model evaluation of aerosols over South Asia: common problems and possible causes, Atmos. Chem. Phys., 15, 5903-5928, doi:10.5194/acp-15-5903-2015, 2015.
Passant, N. R.: Speciation of UK emissions of non-methane volatile organic compounds, Tech. rep., AEA Technology Report ENV-05452002, Culham, Abington, UK, available at: https://uk-air.defra.gov.uk/assets/documents/reports/empire/ AEAT_ENV_0545_final_v2.pdf (last access: 24 May 2016), 2002.

Pöschl, U.: Atmospheric aerosols: Composition, transformation, climate and health effects, Angew. Chemie - Int. Edn., 44, 7520 7540, doi:10.1002/anie.200501122, 2005.

Presto, A. A., Miracolo, M. A., Donahue, N. M., and Robinson, A. L.: Secondary Organic Aerosol Formation from High- $\mathrm{NO}_{x}$ Photo-Oxidation of Low Volatility Precursors: $n$-Alkanes, Environ. Sci. Technol., 44, 2029-2034, doi:10.1021/es903712r, 2010.

Putaud, J. P., Van Dingenen, R., Alastuey, A., Bauer, H., Birmili, W., Cyrys, J., Flentje, H., Fuzzi, S., Gehrig, R., Hansson, H. C., Harrison, R. M., Herrmann, H., Hitzenberger, R., Hüglin, C., Jones, A. M., Kasper-Giebl, A., Kiss, G., Kousa, A., Kuhlbusch, T. A. J., Löschau, G., Maenhaut, W., Molnar, A., Moreno, T., Pekkanen, J., Perrino, C., Pitz, M., Puxbaum, H., Querol, X., Rodriguez, S., Salma, I., Schwarz, J., Smolik, J., Schneider, J., Spindler, G., ten Brink, H., Tursic, J., Viana, M., Wiedensohler, A., and Raes, F.: A European aerosol phenomenology - 3: Physical and chemical characteristics of particulate matter from 60 rural, urban, and kerbside sites across Europe, Atmos. Environ., 44, 1308-1320, doi:10.1016/j.atmosenv.2009.12.011, 2010.

Pye, H. O. T. and Seinfeld, J. H.: A global perspective on aerosol from low-volatility organic compounds, Atmos. Chem. Phys., 10, 4377-4401, doi:10.5194/acp-10-4377-2010, 2010.

R Core Team: R: A Language and Environment for Statistical Computing, R Foundation for Statistical Computing, Vienna, Austria, http://www.R-project.org/ (last access: 24 May 2016), 2014.

Robinson, A. L., Donahue, N. M., Shrivastava, M. K., Weitkamp, E. A., Sage, A. M., Grieshop, A. P., Lane, T. E., Pierce, J. R., and Pandis, S. N.: Rethinking organic aerosols: Semivolatile emissions and photochemical aging, Science, 315, 1259-1262, doi:10.1126/science.1133061, 2007.

Schauer, J. J., Kleeman, M. J., Cass, G. R., and Simoneit, B. R. T.: Measurement of Emissions from Air Pollution Sources. 1. C1 through C29 Organic Compounds from Meat Charbroiling, Environ. Sci. Technology, 33, 1566-1577, doi:10.1021/es980076j, 1999.

Schulz, M., Gauss, M., Benedictow, A., Jonson, J. E., Tsyro, S., Nyiri, A., Simpson, D., Steensen, B. M., Klein, H., Valdebenito, A., Wind, P., Kirkevåg, A., Griesfeller, J., Bartnicki, J., Olivie, D., Grini, A., Iversen, T., Seland, ., Semeena, S. V., Fagerli, H., Aas, W., Hjellbrekke, A., Mareckova, K., Wankmuller, R., Schneider, P., Solberg, S., Svendby, T., Liu, L., Posch, M., Vieno, M., Reis, S., Kryza, M., Werner, M., and Walaszek, K.: Transboundary Acidification, Eutrophication and Ground Level Ozone in Europe in 2011, Tech. rep., Norwegian Meteorological Institute, Oslo, Norway, 1-205, 2013.

Shrivastava, M., Fast, J., Easter, R., Gustafson Jr., W. I., Zaveri, R. A., Jimenez, J. L., Saide, P., and Hodzic, A.: Modeling organic aerosols in a megacity: comparison of simple and complex representations of the volatility basis set approach, Atmos. Chem. Phys., 11, 6639-6662, doi:10.5194/acp-11-6639-2011, 2011.

Shrivastava, M., Easter, R. C., Liu, X., Zelenyuk, A., Singh, B., Zhang, K., Ma, P., Chand, D., Ghan, S., Jimenez, J. L., Zhang, Q., Fast, J., Rasch, P. J., and Tiitta, P.: Global transformation and fate 
of SOA: Implications of low-volatility SOA and gas-phase fragmentation reactions, J. Geophys. Res.-Atmos., 120, 4169-4195, doi:10.1002/2014JD022563, 2015.

Shrivastava, M. K., Lane, T. E., Donahue, N. M., Pandis, S. N., and Robinson, A. L.: Effects of gas particle partitioning and aging of primary emissions on urban and regional organic aerosol concentrations, J. Geophys. Res.-Atmos., 113, 1-16, doi:10.1029/2007jd009735, 2008.

Simpson, D., Yttri, K. E., Klimont, Z., Kupiainen, K., Caseiro, A., Gelencser, A., Pio, C., Puxbaum, H., and Legrand, M.: Modeling carbonaceous aerosol over Europe: Analysis of the CARBOSOL and EMEP EC/OC campaigns, J. Geophys. Res.-Atmos., 112, 126, doi:10.1029/2006jd008158, 2007.

Simpson, D., Benedictow, A., Berge, H., Bergström, R., Emberson, L. D., Fagerli, H., Flechard, C. R., Hayman, G. D., Gauss, M., Jonson, J. E., Jenkin, M. E., Nyíri, A., Richter, C., Semeena, S. V., Tsyro, S., Tuovinen, J. P., Valdebenito, A., and Wind, P.: The EMEP MSC-W chemical transport model - technical description, Atmos. Chem. Phys., 12, 7825-7865, doi:10.5194/acp-127825-2012, 2012.

Spracklen, D. V., Jimenez, J. L., Carslaw, K. S., Worsnop, D. R., Evans, M. J., Mann, G. W., Zhang, Q., Canagaratna, M. R., Allan, J., Coe, H., McFiggans, G., Rap, A., and Forster, P.: Aerosol mass spectrometer constraint on the global secondary organic aerosol budget, Atmos. Chem. Phys., 11, 12109-12136, doi:10.5194/acp-11-12109-2011, 2011.

Tsigaridis, K., Daskalakis, N., Kanakidou, M., Adams, P. J., Artaxo, P., Bahadur, R., Balkanski, Y., Bauer, S. E., Bellouin, N., Benedetti, A., Bergman, T., Berntsen, T. K., Beukes, J. P., Bian, H., Carslaw, K. S., Chin, M., Curci, G., Diehl, T., Easter, R. C., Ghan, S. J., Gong, S. L., Hodzic, A., Hoyle, C. R., Iversen, T., Jathar, S., Jimenez, J. L., Kaiser, J. W., Kirkevåg, A., Koch, D., Kokkola, H., Lee, Y. H., Lin, G., Liu, X., Luo, G., Ma, X., Mann, G. W., Mihalopoulos, N., Morcrette, J.-J., Müller, J.-F., Myhre, G., Myriokefalitakis, S., Ng, N. L., O'Donnell, D., Penner, J. E., Pozzoli, L., Pringle, K. J., Russell, L. M., Schulz, M., Sciare, J., Seland, Ø., Shindell, D. T., Sillman, S., Skeie, R. B., Spracklen, D., Stavrakou, T., Steenrod, S. D., Takemura, T., Tiitta, P., Tilmes, S., Tost, H., van Noije, T., van Zyl, P. G., von Salzen, K., Yu, F., Wang, Z., Wang, Z., Zaveri, R. A., Zhang, H., Zhang, K., Zhang, Q., and Zhang, X.: The AeroCom evaluation and intercomparison of organic aerosol in global models, Atmos. Chem. Phys., 14, 10845-10895, doi:10.5194/acp-1410845-2014, 2014

Tsimpidi, A. P., Karydis, V. A., Zavala, M., Lei, W., Molina, L., Ulbrich, I. M., Jimenez, J. L., and Pandis, S. N.: Evaluation of the volatility basis-set approach for the simulation of organic aerosol formation in the Mexico City metropolitan area, Atmos. Chem. Phys., 10, 525-546, doi:10.5194/acp-10-525-2010, 2010.

Tsimpidi, A. P., Karydis, V. A., Pandis, S. N., and Lelieveld, J.: Global combustion sources of organic aerosols: Model comparison with 84 AMS factor analysis data sets, Atmos. Chem. Phys. Discuss., doi:10.5194/acp-2015-989, in review, 2016.

Ulbrich, I. M., Canagaratna, M. R., Zhang, Q., Worsnop, D. R., and Jimenez, J. L.: Interpretation of organic components from Positive Matrix Factorization of aerosol mass spectrometric data, Atmos. Chem. Phys., 9, 2891-2918, doi:10.5194/acp-9-2891-2009, 2009
USEPA: Integrated Science Assessment for Particulate Matter (Final Report, http://cfpub.epa.gov/ncea/cfm/recordisplay.cfm? deid=216546 (last access: 24 May 2016), 2009.

Vieno, M., Dore, A. J., Stevenson, D. S., Doherty, R., Heal, M. R., Reis, S., Hallsworth, S., Tarrason, L., Wind, P., Fowler, D., Simpson, D., and Sutton, M. A.: Modelling surface ozone during the 2003 heat-wave in the UK, Atmos. Chem. and Phys., 10, 7963 7978, doi:10.5194/acp-10-7963-2010, 2010.

Vieno, M., Heal, M. R., Hallsworth, S., Famulari, D., Doherty, R. M., Dore, A. J., Tang, Y. S., Braban, C. F., Leaver, D., Sutton, M. A., and Reis, S.: The role of long-range transport and domestic emissions in determining atmospheric secondary inorganic particle concentrations across the UK, Atmos. Chem. Phys., 14, 8435-8447, doi:10.5194/acp-14-8435-2014, 2014.

Wickham, H.: ggplot2: Elegant Graphics for Data Analysis, ISBN 978-0-387-98140-6, Springer-Verlag, New York, USA, available at: http://ggplot2.org (last access: 24 May 2016), 2009.

Wiedinmyer, C., Akagi, S. K., Yokelson, R. J., Emmons, L. K., AlSaadi, J. A., Orlando, J. J., and Soja, A. J.: The Fire INventory from NCAR (FINN): a high resolution global model to estimate the emissions from open burning, Geosci. Model Dev., 4, 625641, doi:10.5194/gmd-4-625-2011, 2011.

Xu, L., Suresh, S., Guo, H., Weber, R. J., and Ng, N. L.: Aerosol characterization over the southeastern United States using highresolution aerosol mass spectrometry: spatial and seasonal variation of aerosol composition and sources with a focus on organic nitrates, Atmos. Chem. Phys., 15, 7307-7336, doi:10.5194/acp15-7307-2015, 2015.

Xu, L., Williams, L. R., Young, D. E., Allan, J. D., Coe, H., Massoli, P., Fortner, E., Chhabra, P., Herndon, S., Brooks, W. A., Jayne, J. T., Worsnop, D. R., Aiken, A. C., Liu, S., Gorkowski, K., Dubey, M. K., Fleming, Z. L., Visser, S., Prévôt, A. S. H., and Ng, N. L.: Wintertime aerosol chemical composition, volatility, and spatial variability in the greater London area, Atmos. Chem. Phys., 16, 1139-1160, doi:10.5194/acp-16-1139-2016, 2016.

Young, D. E., Allan, J. D., Williams, P. I., Green, D. C., Flynn, M. J., Harrison, R. M., Yin, J., Gallagher, M. W., and Coe, H.: Investigating the annual behaviour of submicron secondary inorganic and organic aerosols in London, Atmos. Chem. Phys., 15, 63516366, doi:10.5194/acp-15-6351-2015, 2015a.

Young, D. E., Allan, J. D., Williams, P. I., Green, D. C., Harrison, R. M., Yin, J., Flynn, M. J., Gallagher, M. W., and Coe, H.: Investigating a two-component model of solid fuel organic aerosol in London: processes, $\mathrm{PM}_{1}$ contributions, and seasonality, Atmos. Chem. Phys., 15, 2429-2443, doi:10.5194/acp-152429-2015, 2015b.

Zhang, Q. J., Beekmann, M., Drewnick, F., Freutel, F., Schneider, J., Crippa, M., Prevot, A. S. H., Baltensperger, U., Poulain, L., Wiedensohler, A., Sciare, J., Gros, V., Borbon, A., Colomb, A., Michoud, V., Doussin, J., Denier van der Gon, H. A. C., Haeffelin, M., Dupont, J., Siour, G., Petetin, H., Bessagnet, B., Pandis, S. N., Hodzic, A., Sanchez, O., Honoré, C., and Perrussel, O.: Formation of organic aerosol in the Paris region during the MEGAPOLI summer campaign: evaluation of the volatilitybasis-set approach within the CHIMERE model, Atmos. Chem. Phys., 13, 5767-5790, doi:10.5194/acp-13-5767-2013, 2013. 